que el hospital tenía asignados desde el acta de fundación, junto a la cuadra de San Agustín.

De esta forma y bajo la advocación de San Juan Evangelista se dio por fundado definitivamente el Hospital de la Caridad $^{78}$, en 1585 , nombrándose como primer mayordomo a Juan de San Juan Bermeo, regidor en ese momento de la ciudad. Esta primera casa de salud fue pequeña e inadecuada, por lo que cuando se produjo la epidemia de tifus de 1588 y que duró hasta 1589, se resolvió volver al primitivo sitio señalado en el acta de fundación y construir un nuevo hospital que fue levantado en la media cuadra comprendida entre las actuales calles de Gran Colombia y Luis Cordero ${ }^{79}$.

Aunque el patrón del hospital de Cuenca fue el Cabildo, a partir de 1599 nos encontraremos la presencia de religiosos atendiendo a los enfermos del hospital. Serán los hermanos de San Juan de Dios primero y, años después, los betlemitas. No sabemos por qué no llegaron a instalar nunca casas los juaninos, pero sí por qué no lo hicieron los jesuitas, ya que si bien prestaban caridad cristiana con los enfermos, su auténtica labor, era la educativa. Otra orden religiosa unida a la suerte del hospital, fue la mercedaria, que intentaron fundar ya casas en 1692 pero que no sería hasta 1713 que tras comprar las casas de D. Pedro de la Cuesta Pedrosa, de las que tomaría posesión fray Pablo de Santo Tomás, no instalarían casa-hospicio a la que ya hace una breve alusión el jesuita P. Velasco al decir: los mercedarios sólo tienen una mala casa de hospicio con pequeña capilla ${ }^{80}$. Pero no fue hasta la segunda mitad del siglo XVIII cuando se instalaron formalmente en la ciudad, en los solares que ya tenían y que intentaron cambiar a través de su prior, fray Juan de Villalta Castañeda por las del hospital, de manera que ellos se acercarían más al centro y el hospital se alejaría un poco. No sabemos el por qué los trámites no llegaron a buen fin, pero lo cierto es que el convento mercedario siguió ocupando sus casas propias hasta su extinción en 1787 en que pasó a los Oblatos que lo

${ }^{78}$ Los hospitales reales de Caridad eran casas designadas a recoger indios, pobres o peregrinos para prodigarles un alivio de sus males y prepararles para la muerte con la administración de los últimos sacramentos.

${ }^{79}$ Cordero Jaramillo, L. (1989): «Hospitales de la época colonial». El libro de Cuenca, T.II. .Cuenca: Editores y Publicistas, p. 88.

${ }^{80}$ Velasco, J, de (1983): «Gobierno de Cuenca» León, L. A. en Compilación de Crónicas, relatos y descripciones de Cuenca y su Provincia, T. II. Cuenca: BCE, p. 250 
convirtieron en Santuario del Padre Matovelle, tal y como se conserva hasta el presente $^{81}$.

Los que sí se instalaron definitivamente fueron los hermanos de la orden betlemita, que tras varias peticiones e informes por parte del cabildo cuencano, se instalaron en Cuenca en 1742 tras una administración ruinosa por parte de los mayordomos. Entretanto, la Audiencia comenzó a designar directamente a los administradores del Hospital de la Caridad. Desde 1737 a 1743, se siguieron nombrando laicos, pero fue en 1744 cuando se designó por primera vez un religioso y además betlemita, fray Fernando de San Simón, constituyendo el primer paso para el asentamiento de la orden en Cuenca. Bajo la administración religiosa pronto florecieron las rentas y se comenzaron las obras de reparación de la iglesia y el hospital se trasformó en una eficiente casa de salud con enfermerías mixtas, botica y biblioteca, donde los enfermos eran atendidos con diligencia y solicitud.

E1 hospital de Belén, cambió su nombre por el de Hospital Militar con la llegada de las tropas independentistas del General Sucre el 5 de marzo de 1822, que siguió en manos betlemitas hasta 1827, en que el padre prefecto fray José de San Miguel solicitó que el hospital, ante el estado de ruina, fuese trasladado al hospicio y convento de la Merced. En 1831 murió, siendo sustituido, aunque sólo al frente de la botica por fray Raimundo del Carmen, que en el momento que entregó las cuentas del hospital al Cabildo, supuso la extinción de al comunidad religiosa en Cuenca, quedándose además a ciudad, sin hospital que atendiese a sus enfermos hasta que en 1872 se fundó en de San Vicente Paúl.

Relación de los hospitales coloniales en Ecuador

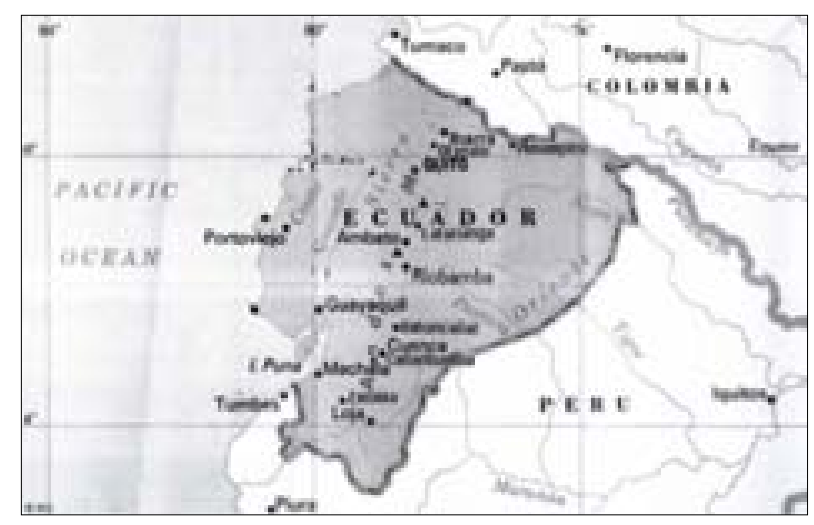

${ }^{81} \mathrm{http}: / /$ www.misionerosoblatos.org/html/historia.htm (12/2/2003) 


\title{
PREPARARSE A BIENMORIR: LAS ÚLTIMAS VOLUNTADES DEL OBISPO CUENCANO ANDRÉS QUINTIÁN Y PONTE ${ }^{1}$
}

\author{
$\mathrm{M}^{\mathrm{a}}$ Isabel VIFORCOS MARINAS \\ Universidad de León
}

\begin{abstract}
RESUMEN: Queremos dar a conocer en el presente trabajo la última voluntad de don Andrés Quintián, obispo de Cuenca (Ecuador) a través de los testamentos redactados en 1813, último año de su vida, conservados en el Archivo Nacional de Cuenca y que hasta ahora eran inéditos. Tras una breve panorámica sobre la Cuenca de las últimas décadas del periodo colonial, nos adentramos en la figura del controvertido prelado. Conocido por su defensa a ultranza de la causa realista, el testamento además de aportar algunos detalles desconocidos sobre su biografía, nos da luz sobre su espiritualidad, talante y entorno social. El artículo finaliza con un análisis del último testamento, en el que se pone de relieve tanto la similitud formal con los modelos registrados a partir de la segunda mitad del XVII, como sus peculiaridades de contenido, y se cierra con su trascripción.
\end{abstract}

PALABRAS CLAVE: testamento, obispo, Cuenca (Ecuador), 1813.

ABSTRACT: It is our purpose in the present paper to show the last wishes of don Andrés Quintián, bishop of Cuenca (Ecuador), as registered in the wills drawn up in 1813, the last year of his life. They are kept in the "Archivo Nacional de Cuenca" and have not been published until now. After a brief survey of Cuenca in the last decades of the colonial period, we try to introduce the figure of this controverted prelate. He is well known for his out-and-out defence of the royalist cause. Besides contributing some new unknown details about his biography, his last will and testament sheds some light on his spirituality, temperament and social background. The article ends with an assessment of that will, which highlights both the formal similarity with other models common after the second part of the $17^{\text {th }}$ century and its peculiar contents, and closes with its transcription.

KEY WORDS: Will, bishop, Cuenca (Ecuador), 1813

${ }^{1}$ El trabajo ha sido realizado en el marco de un proyecto concedido por el Vicerrectorado de Investigación de la Universidad de León: Estudio de una elite colonial. El clero de cuenca (Ecuador) a través de sus últimas voluntades. Referencia: ULE2003-21. 


\section{PANORÁMICA DEL OBISPADO}

Cuenca era una gobernación joven -1770- y un obispado aún más novel. La idea de elevar Santa Ana de los Ríos de Cuenca a capital diocesana se empezó a gestar a mitad del siglo XVIII, en tiempos del obispo de Quito Juan Nieto Polo del Águila, pero la decisión real no se manifestó oficialmente hasta la real cédula de $1772^{2}$. En 1774 ya estaban culminadas las diligencias de deslinde y división del nuevo obispado, que corrieron a cargo del oidor de la Audiencia quiteña Serafín Veyán, designado por el virrey de Santa $\mathrm{Fe}$, y de los delegados nombrados por el obispo payanés Jerónimo Antonio de Obregón y Mena, que fueron el maestrescuela de la iglesia de Popayán, don Miguel de Unda y Lema, y el cura de Novita don Mariano Grijalva ${ }^{3}$. Cinco años más tarde, el 13 de junio de 1779 se despachaba la cédula de erección, aunque todavía habrían de pasar algunos años más para que se hiciese efectiva, a causa de la convulsión de los tiempos y la hostil relación con Inglaterra. En efecto, no será hasta la provisión real de 22 de agosto de 1785 , cuando Carlos III ponga en marcha y comunique el inicio del proceso de selección del nuevo mitrado, mediante la habitual consulta al Consejo de Cámara ${ }^{4}$.

Despachada la correspondiente bula por Pío VI el 1 de julio de 1786, el primer diocesano sería don José Carrión y Marfil, que dos años antes había sido elegido como obispo auxiliar de Santa Fe. Su estancia en la diócesis cuencana se prolongaría hasta su promoción al obispado de Trujillo, para el que fue nombrado el 3 de julio de 1798. Sus casi doce años de pontificado se consumirían entre los continuados e infructuosos intentos por dotar a su iglesia de una catedral digna -el obispo la soñaba como la de su Málaga natal- ${ }^{5}$ y los constantes esfuerzos por elevar el nivel moral de un clero y una sociedad que por la lejanía del obispado de Quito, al que hasta entonces había pertenecido, estaba bastante degradada. No nos detendremos en el negativo panorama que arrojan los informes que por la vía

2 AHM/C, Libros de Cabildo (1760-1773), ff. 373-374. Transcribe la cédula J. CHACÓN ZHAPÁN (1990), Historia del corregimiento de Cuenca 1557-1773, Quito: Banco Central del Ecuador, pp. 666-667.

${ }^{3}$ M. J. de Ayala (1991), Diccionario de gobierno y legislación de Indias, (ed. M. M. del Vas Mingo), Madrid: Cultura Hispánica, pp. 90-92.

${ }^{4}$ La provisión, en la que se sintetiza el largo proceso seguido hasta la erección, se transcribe en J. CHACÓn ZHAPÁN (1990), Historia del corregimiento de Cuenca..., pp. 671-675.

${ }^{5}$ Sobre el deseo de la construcción catedralicia y sus problemas J. PANIAGUA PÉREZ (1993), "Noticias socioeconómicas del austro ecuatoriano obtenidas en el proceso de la nunca construida catedral colonial de Cuenca", Anuario Jurídico y Económico escurialense XXVI (Homenaje a Fr. José López Ortiz), Vol. I, San Lorenzo de El Escorial, pp. 515-541. 
reservada dirige entre 1788 y 1790 al secretario de Indias para asuntos de Gracia y Justicia, don Antonio Porlier, tan sólo evocaremos los denunciados desordenes de los monasterios femeninos, especialmente del de la Concepción, y la suspensión de buena parte del clero secular, por la escasa preparación para su ministerio, evidenciada en el examen realizado en 1790, en que se halló sacerdote que, como Ignacio Macías, ni siquiera sabía qué cosa es signarse y santiguarse ${ }^{, 6}$.

Después del recto obispo Carrión se abriría un largo periodo de sedevacantía de prácticamente nueve años, pues el designado como sucesor sería José Cuero y Caicedo, que no llegaría a entrar en su sede, por ser elevado a la de Quito el 23 de diciembre de 1801, y a éste le sucedería Francisco Javier Carrión y Lafita, quiteño de nacimiento y canónigo de Cuenca, que moriría en 1804, el mismo año de su consagración en Quito ${ }^{7}$.

El 9 de septiembre de 1805 sería designado Andrés Quintián Ponte y Andrade, que tomaría posesión de su sede en 1807 y la regiría hasta su muerte en 1813. El destino no era fácil. El obispado comprendía las provincias de Cuenca, Loja y Guayaquil, además de los pueblos y curatos de Alausí, y a la falta de una dirección pastoral continuada y eficaz, se sumaban las tensiones regionales, especialmente entre la sierra y la costa, o lo que es lo mismo, entre Cuenca y Guayaquil, que ya había manifestado su deseo de constituirse en obispado independiente en 1797 y $1798^{8}$, y el declive socioeconómico que se cernía sobre todo el austro ecuatoriano ya desde finales del siglo XVIII.

En medio de un panorama de tendencia demográfica decreciente $\mathrm{o}$, al menos estacionaria, sólo Cuenca y su región mantienen índices de crecimiento, aunque cada vez más ralentizado, convirtiéndose con sus más de 80.000 habitantes en el núcleo más poblado, cuadriplicando la población guayaquileña. Su desarrollo económico se verá lastrado por una crónica escasez de fuerza trabajo, que se nutría prácticamente de la masa indígena -algo más del $47 \%$ de la población total-, pues la población blanca rehuía, por lo común, el trabajo manual, dedicándose al ámbito administrativo, eclesiástico o comercial, o viviendo de las rentas de sus haciendas, y nunca hubo capital suficiente como para introducir mano de obra esclava en

${ }^{6}$ Sobre la figura de este prelado: R. VARGAS (1961), Historia de la Iglesia en el Perú, 1700-1800, T. IV, Burgos: Imp. Aldecoa, pp. 207-208 y E. REDONDO (1994), «Correspondencia a la vía reservada del obispo malagueño José Carrión y Marfil», en AA. VV. El reino de Granada y el Nuevo Mundo, Vol. I, Granada: Diputación provincial, pp. 707-714.

\footnotetext{
${ }^{7}$ A. EgAÑA (1966), Historia de la Iglesia en la América española, Madrid: BAC, p. 944.

8 J. PANIAGUA PÉREZ (1993), «Noticias socioeconómicas del austro ecuatoriano...», p. 540.
} 
cantidad, de modo que el esclavo negro, concebido más como propiedad suntuaria, fue siempre escaso en numero y se dedicó preferentemente a tareas domésticas ${ }^{9}$.

Las actividades productivas estaban en una situación de deterioro y estancamiento. La producción agrícola no alcanzaba los niveles de excedentes suficientes para su comercialización. El minifundio era, al contrario de lo que ocurría en el resto de la sierra ecuatoriana, la forma más habitual de tenencia de la tierra, particularmente en Azuay y Cañar; por supuesto que no faltaban haciendas medias y grandes, normalmente ganaderas, en torno a Cuenca, Girón o Cañar, donde también las había dedicadas al cultivo de trigo, y también algunas de caña en el área de Paute, siendo el sector eclesiástico el mayor latifundista.

La actividad minera, particularmente la extracción aurífera, hacía tiempo que había decaído completamente, aunque todavía se conservara el mito de la potencial riqueza minera en la mayoría de los informes que, para la reactivación de la región, envían al presidente de la Audiencia de de Quito, los cabildos secular y eclesiástico de Cuenca ${ }^{10}$.

La extracción de la cascarilla en Loja, y cada vez más en Cuenca, se mantenía como una de las actividades económicas más lucrativas y la principal fuente de ingresos monetarios, pero también se vio afectada por los trastornos del mercado provocados por las continuas guerras europeas y por la política de la Corona de empezar, a partir de 1785, a acotar los montes más productivas, para el abastecimiento de la real botica.

La producción textil de bayetas y tocuyo sería en los últimos tiempos del periodo colonial el eje dinamizador de la economía cuencana. La producción, de

9 Sobre estos aspectos sociodemográficos: J. PANIAGUA PÉREZ, (1986) «La sociedad en Cuenca del Perú a finales del siglo XVIII», en Primeiras Jornadas de Historia Moderna, Vol. II, Lisboa, pp. 1113-1127 y «La esclavitud en Cuenca del Perú (1770-1810)», Estudios Humanísticos 8 (1986), pp. 121-143; M. LuCENA SALMORAL (1994), «La población del reino de Quito en la época de reformismo borbónico: circa 1784», Revista de Indias, n 200, pp. 33-81.

10 Joaquín de Merisalde Y SAntisteban (1957) será una de las pocas voces que se atreva a clamar contra ese mito en su Relación histórica, política y moral de la ciudad de Cuenca, Quito, p. 64. Sin embargo su persistencia puede constatarse todavía en la relación que sobre Loja suscribe, en 1808, Vicente de Olmedo y Rodríguez, en la que afirma: Aquí y en toda la provincia hay infinitas vetas de oro y plata con diversas clases e riqueza y pobreza, según sus muestras, pero no hay sujeto que se dedique a catear una, para más adelante insistir en la bondad y abundancia del oro del cerro de San Antonio de Zaruma. P. PONCE LeIVA ed. (1992), Relaciones histórico geográficas de la Audiencia de Quito (siglos XVI-XIX), vol. II, Madrid: Consejo Superior de Investigaciones científicas, p. 758. 
calidad deficiente, se elaboraba por los indígenas en talleres domésticos, mientras su comercialización estaba monopolizada por un reducido grupo de comerciantes conocidos como los de la carrera de Lima, por ser éste el mercado al que se dirigían con preferencia, aunque a partir de 1810 el guayaquileño llegará a superarlo.

Dentro de este panorama de general contracción, la costera Guayaquil, que había basado su desarrollo en la producción y comercialización de cacao, era la provincia del obispado que estaba en una mejor situación, especialmente desde que el obispo Carrión consiguiera la reapertura del comercio con México, acabando así con la suspensiones al libre-comercio decretadas en 1778 y 1785, en beneficio del cacao caraqueño ${ }^{11}$. Baste un solo dato para ilustrar esta relativa bonanza: en 1794 el monto total de los diezmos del obispado alcanzó los 55.249 pesos, de los que 27.093 pesos -el 49\%- correspondían a la jurisdicción guayaquileña ${ }^{12}$.

Al panorama descrito ${ }^{13}$ habría que añadir otros males de la tierra: la crónica falta de circulante, a la que no era ajena la tendencia a invertir en objetos suntuarios o en tierras, que no se concebían como explotaciones a rentabilizar, sino como timbre de honra y distinción, contribuyendo con ello a la descapitalización de todas las actividades económicas; el incremento de las exacciones fiscales tras las reformas borbónicas, gran parte de las cuales salía de las cajas reales de Cuenca con destino a Quito, Cartagena o Madrid ${ }^{14}$; y finalmente la crisis política a la que darían lugar los acontecimientos españoles de 1808, que vendría a abortar el repunte económico experimentado en la primera década del siglo XIX.

Quintián Ponte y Andrade se va a encontrar, en consecuencia, un obispado con dificultades económicas y rentas limitadas, carente de catedral y seminario, con un clero secular insuficiente, no tanto por número, como por preparación y catadura moral, y una cumplida representación de regulares, pues, circunscribiéndonos a la

${ }^{11}$ Acerca de la situación de Guayaquil: Ma L. LAVIANa CuETOS (1987), Guayaquil en el siglo XVIII. Recursos naturales y desarrollo económico, Sevilla: Escuela de Estudios Hispano-Americanos, CSIC, especialmente pp. 171 y ss.

12 Tomamos el dato de J. Paniagua Pérez (1993), «Noticias socioeconómicas del austro ecuatoriano...», p. 541.

${ }^{13}$ En él hemos seguido básicamente el trabajo de S. Vega Ugalde (1986) «Cuenca en los movimientos independentistas», Revistas del Archivo Nacional de Historia. Sección Azuay, n 6 , pp. 9-48.

${ }^{14}$ L. ESPINOSA (1979), «Política fiscal de la provincia de Cuenca, reseña histórica-presupuestaria. 1779-1861», Revista del Archivo Nacional de Cuenca, nº 1, p. 73. 
capital diocesana, encontramos en ella conventos de la orden de Santo Domingo, de San Francisco, de San Agustín y de la Merced, un hospital de San Lázaro regido por los betlemitas y dos monasterios femeninos: uno de concepcionistas y otro de carmelitas. El cabildo catedralicio, que según la erección debería estar compuesto por deán, arcediano, chantre y maestrescuela, hasta diez canonicatos, seis raciones y otras tantas medias raciones, había sido reducido por la propia cédula de 1779, en atención a las escasas rentas del obispado, de manera que las canónigos se habían limitado a dos de oficio -doctoral y penitenciario- y lo mismo el número de racioneros y medio-racioneros ${ }^{15}$. Esta situación habría requerido una amplia actividad pastoral, que los acontecimientos no le permitirían desarrollar, ya que una buena parte de su tiempo y sus trabajos se encauzarían hacia una cerrada defensa de la causa realista, a partir de los movimientos quiteños de 1809 .

\section{DON ANDRÉS QUINTIÁN PONTE Y ANDRADE}

La principal fuente para aproximarnos a su persona es una relación de méritos y servicios, impresa en Madrid en $1797^{16}$. En ella se dice que fue natural de La Coruña, aunque no se especifica la fecha de su nacimiento, que debió ocurrir hacia 1751. Sus padres fueron Bernardo José de Quintián y doña Isabel de Ponte y Andrade, que el memorial menciona como hidalgos notorios del reino de Galicia y que, al menos, tuvieron otros dos hijos, tal vez tres, según se deduce de las mandas testamentarias del obispo, en las que se nombra a su hermano Juan, cuyas hijas residían en Cádiz en 1813, y a su hermana María, que en esa fecha continuaba viviendo en Galicia, además de a unas sobrinas, hijas de don Gregorio de Somoza, del que no se dice si era cuñado del prelado o simplemente primo ${ }^{17}$.

Desconocemos cuándo emigró a América, pero debió de ser a temprana edad, ya que en el memorial de méritos se dice que había sido colegial del seminario de Santo Toribio de Lima, donde se formó en Filosofía y Teología. La celebración del VI Concilio de Lima, convocado por el arzobispo Diego Antonio de Parada, al que asistirá, entre otros, el obispo de Concepción fray Pedro Ángel de Espiñeira, propiciará el encuentro, en 1772, entre este prelado, también gallego, y su paisano Quintián. Y de esta coincidencia se derivaría su traslado a la sede de la Concepción, a donde acudiría reclamado por Espiñeira, que sería quien le ordenaría

\footnotetext{
${ }^{15}$ M. J. Ayala (1991), Diccionario de gobierno..., pp. 90-92.

${ }^{16}$ La recoge J. T. Medina (1965), Biblioteca Hispano-Chilena (1523-1817), T. III, Ámsterdam: N. Israel, pp. 258-261.

${ }^{17}$ Vid apéndice, cláusulas 14, 15 y 16.
} 
de subdiácono, para hacerse cargo de la secretaria episcopal, oficio para el que fue nombrado en 1777, y para colaborar en el colegio seminario de San Carlos de Borromeo, reinstaurado ese mismo año ${ }^{18}$.

La muerte de Espiñeira, el 9 de febrero de 1778, dejó a Andrés Quintián sin un importante valedor, aunque muy recomendado por la memoria que el prelado elaboró en transcurso de su enfermedad. Tal vez con la intención de recibir cuanto antes las órdenes que le faltaban, se desplazó a Santiago de Chile, donde en abril de 1778 recibiría el diaconado y el presbiteriado de manos del obispo don Manuel de Alday. Su vuelta a la Concepción fue casi inmediata, pues, de acuerdo con el memorial de méritos, el 9 de mayo de ese mismo año el gobernador del obispado en sede vacante, Francisco de Arechavala y Olivarría, le confería el grado de doctor en Teología, la licencia para predicar y confesar en toda la diócesis, y, pocos meses después, recomendaba su nombramiento como vice-rector del seminario.

El nuevo prelado de Concepción, Francisco José de Marán, llegaba a su iglesia en 1780 y fueran las excelentes referencias recibidas en su diócesis del clérigo Quintián, o fuera que lo conociera de sus tiempos de seminarista en Lima, donde el obispo había sido comisario de la Inquisición en 1771, de inmediato le brindó todo su apoyo. En 1780 ratificó sus licencias para confesar y predicar, le nombró examinador sinodal y defensor de matrimonios y hasta le ofreció la parroquia del Sagrario, que Quintián no aceptó, parece que en atención a la muchas dedicación que el seminario le exigía ${ }^{19}$. Sí aceptaría en cambio el ofrecimiento de actuar como capellán del batallón de infantería chileno, que en ese momento dirigía, como comandante interino, Pedro Quijada, militar vinculado por nacimiento y carrera al reino chileno ${ }^{20}$. Ese mismo año, Concepción se veía afectada por una epidemia proveniente de Santiago y conocida como el malcito y el obispo Francisco José Marán no escatimó esfuerzos, habilitando para atender a los afectados un hospital

${ }^{18}$ H. RodRíGuez Villegas (1992), «Andrés Quintián y Ponte», en Episcopologio chileno 15611815 (Dir. C. Oviedo cavada), T. IV, Santiago de Chile: Universidad Católica de Chile, p. 616.

${ }^{19}$ H. Rodríguez ViLLegas (1992), «Andrés Quintián y Ponte», p. 619.

${ }^{20}$ Después de una dilatada carrera militar, siendo brigadier de la Concepción, le sería ofrecido en 1808, con carácter interino, el cargo de gobernador y capitán general de Chile, que no aceptó por su avanzada edad, cediendo sus derechos al también brigadier Francisco Antonio García Carrasco (18081810). Algún dato sobre Pedro Quijada puede hallarse en L. LEÓN (1982), «La corona española y las guerras intestinas entre los indígenas de Araucania, Patagonia y La Pampa, 1760-1806», Nueva Historia, 5 y H. PACHECO SILVA (1998), «El aporte de la elite intelectual al proceso de 1810: la figura de Juan Martínez de Rozas», Revista de Historia. Universidad de Concepción, 8, pp. 43-63. 
para mujeres en la casa de ejercicios, recayendo, por decisión suya, buena parte de la atención espiritual y material del hospital, en Andrés Quintián ${ }^{21}$.

De lo hasta aquí reseñado va surgiendo la figura de un clérigo laborioso, plenamente entregado al ministerio sacerdotal, y fiel ejecutor de los encargos encomendados por sus superiores. El informe que sobre sus méritos elabora el provisor y vicario general del obispado en 1781 nos brinda, además, la oportunidad de acercarnos a su religiosidad, pues en él se informa de los constantes esfuerzos por extender en la catedral las pláticas de la escuela de Cristo. Era ésta una línea de espiritualidad inspirada lejanamente en el Oratorio italiano de San Felipe de Neri, que había nacido en Madrid, en 1653, a impulso de Juan Bautista Ferruza y que se extendería por buena parte de los territorios de la Corona, incluida Hispanoamérica. Integrada por eclesiásticos y seglares, se caracterizó por su marcado contrarreformismo y una moral ascética y rigorista muy acorde con los aires filojansenistas y episcopalista del tiempo que nos ocupa y que, no casualmente, fue el del impulso de la beatificación del obispo Juan Palafox y Mendoza $^{22}$.

Al positivo informe del provisor del obispado se sumarían el del cabildo secular de Concepción, el del obispo Marán y hasta el del gobernador -entonces interino y desde 1783 titular- don Ambrosio O’Higgins, que se convertiría en uno de los principales valedores de Quintián. Y el resultado no se haría esperar, pues el 25 de noviembre de 1782, se expedía la real presentación para el oficio de maestrescuela catedralicio $^{23}$.

Se abre a partir de ese nombramiento un periodo en el que la carrera de nuestro clérigo parece detenerse, a pesar de que en 1789 el Tribunal de la Inquisición de Lima lo nombra oficial del Santo Oficio ${ }^{24}$. Para darle un nuevo impulso, el obispo Francisco José Marán, al ser promovido a la diócesis de Santiago, vuelve a representar, en 1795, los méritos de su colaborador, solicitando, por razones de

21 A. Dougnac Rodríguez (1992), «Francisco José Marán», en Episcopologio Chileno 15611815, (dir. C. Oviedo Cavada), T. III, Santiago de Chile: Universidad Católica de Chile, pp. 66-67 y 94.

22 M. VAlero Moreno (1989), «La escuela de Cristo: su vida, organización y espiritualidad barroca» en C. Álvarez SAntaló, Ma J. Buxó I Rey, S. Rodríguez Becerra (coords.), La religiosidad popular, V. III, Hermandades, romerias y santuarios, Barcelona: Anthropos, pp.507-529.

23 R. Magdaleno (1954), Títulos de Indias, Valladolid: Patronato Nacional de Archivos Históricos, p. 604.

${ }^{24}$ H. RodRíGUeZ Villegas (1992), «Andrés Quintián y Ponte», p. 620. 
salud, un traslado a otra iglesia más al norte y con clima más benigno. Tal vez realmente la salud de Quintián empezase a resentirse, pero no hemos de olvidar que el argumento de lo muy enfermizo que resultaba el clima del obispado concepcionista, fue el preferido por Marán en sus repetidas peticiones de promoción a otra diócesis, por lo que, sin rechazar totalmente el informe episcopal, nos parece más ajustado a la realidad el memorial elevado a Carlos IV, en 1796, por Ambrosio O'Higgins; en el se expone el estado de abatimiento y aflicción en que había hallado a Quintián, a su paso por Concepción rumbo Lima, y cómo se sentía postergado y olvidado, a pesar de los diecinueve años de buenos servicios en la diócesis. Como apoyo a todas estas gestiones, don Andrés decide entonces dar a la imprenta la relación de méritos aludida, que lleva fecha de 14 de febrero de $1797^{25}$.

Antes de que todas estas gestiones se hubiesen ultimado, se nombraba a Quintián subdelegado de la Santa Cruzada. El oficio no era para satisfacer las expectativas de nuestro clérigo, que vio pasar los meses sin resultados acordes a sus ambiciones. La demora le llevó a adoptar una de las vías más expeditivas para lograr promociones en la Corte, pues en septiembre de 1801 otorgó poder, a favor de los vecinos de Madrid, José Amandaro, Diego de la Vega, Francisco Ximénez de Sarmiento y Nicolás Fernández de Rivera, para que le representasen en los pleitos e instancias que surgieran, o, lo que es lo mismo, para que actuasen de agentes suyos ${ }^{26}$

En 1802, haciendo buena la opinión de Bermúdez de Pedraza $^{27}$, vendría a unirse al mérito de Quintián, la ocasión -vacante del deanato-, y a la recomendación de sus patrocinadores, la buena gestión de sus agentes en la Corte, para que don Andrés pudiera obtener la dignidad de deán de la Concepción ${ }^{28}$.

25 J. T. Medina (1965), Biblioteca Hispano-Chilena (1523-1817), T. III, Ámsterdam, N. Israel, pp. $258-261$.

26 De la formalización de este poder se hace eco H. RodRíGUEZ VILlEGAS (1992), «Andrés Quintián y Ponte», p. 621

${ }^{27}$ F. Bermúdez De Pedraza (1643) (Hospital real de la Corte de enfermos heridos del ánimo de late, su origen, malicia y preservación y medicina curativa de ellos, Granada, p. 122), refiriéndose a los burócratas del tiempo de los Austria, aunque su juicio es extensible al de los Borbón, afirmaba: Ninguno es... de tan claro ingenio que puedan lograrle -el oficio-, si le falta la materia, la ocasión y la recomendación.

${ }^{28}$ R. Magdaleno (1954), Títulos..., p. 603. 
Tres años más tarde, a causa de la muerte del obispo don Tomás de Roa y Alarcón, el cabildo catedralicio le elegiría como vicario capitular de la diócesis. Por entonces, el siempre insatisfecho Francisco José Marán solicitaba su promoción al arzobispado de Lima, vacante por fallecimiento de Domingo González de la Reguera, y proponía como sucesor en la sede santiaguesa a su antiguo colaborador. La petición del mitrado no sería atendida, pero Quintián sí sería elevado a la dignidad episcopal al ser preconizado en 1805 por Pío VII al obispado cuencano ${ }^{29}$. Sería consagrado en Lima por el arzobispo Bartolomé María de las Heras el 2 de febrero de 1807 y allí tendría la oportunidad de conocer al virrey Abascal, trasladado desde el virreinato de la Plata en 1806. Dos meses más tarde llegaría a su sede, que presidiría durante seis años.

A la hora de enjuiciar la labor episcopal de Andrés Quintián todos los estudiosos se muestran unánimes en considerarlo más "un jefe realista" que un pastor diocesano, siguiendo con ello el juicio del provisor Manuel José Caicedo, que afirmó haber visto al pastor de la Iglesia convertido en general del ejército y derramar el dinero del seminario y de otras obras pías, en creación de tropas y perdonar dos años de tributos para entusiasmar más a la gente ${ }^{30}$.

Ciertamente el marco temporal de su episcopado fue excepcional y convulso. Tras los acontecimientos peninsulares de 1808 y poco antes de la formación de la Junta Central Suprema Gubernativa de España e Indias, llegaba a Quito, como presidente de la Audiencia, don Manuel Urries, conde Ruiz de Castilla; su gobierno, oligárquico e inoperante no hizo sino precipitar el movimiento criollo, acaudillado por el Marqués de Selva Alegre, para establecer una Junta de Gobierno del Reino de Quito. Descubierta la conspiración en marzo de 1809, sus líderes no pudieron ser encausados por la "oportuna" desaparición de los expedientes judiciales. De ese modo quedó operativo el movimiento y el 10 de agosto de 1809, tras la renuncia del presiente Urries, se constituía la Junta de Gobierno de Quito, cuya presidencia recaería en Juan Pío Montúfar, marqués de Selva Alegre. Con esa misma fecha se dirigía un oficio al cabildo secular de Cuenca invitándole a reconocer a la Junta quiteña. Aunque no existía unanimidad entre los cuencanos, la acción del gobernador Melchor Aymerich y del obispo Quintián sería decisiva para que Cuenca rechazase a la Junta quiteña y ratificase su juramento de fidelidad a Fernando VII y a la Junta Central Suprema. La misiva remitida por Andrés

${ }^{29}$ R. Magdaleno (1954), Títulos..., p. 499.

${ }^{30}$ M. J. CAICEDO (1980), Viaje imaginario por las provincias limítrofes de Quito y regreso a la capital, publicado por C. R. Tobar en Anales de la Universidad de Quito n $\mathrm{n}^{\circ} 31$, pp. 226-270. 
Quintián el 27 de agosto de 1809, en respuesta a la enviada por Montúfar el día 21 en la que le notificaba su nombramiento de vocal nato de la Junta quiteña, resulta totalmente esclarecedora respecto a sus convicciones realistas. El obispo rechaza el nombramiento en virtud del solemne juramento de fidelidad prestado tras la declaración de Fernando VII; no reconoce autoridad ninguna a la Junta quiteña, puesto que no emana de legítima soberanía; y lamenta la ruptura del orden establecido, que lejos de proporcionar las mil felicidades prometidas por la Junta, no haría sino acarrear infinitos males e infortunios ${ }^{31}$.

En las semanas siguientes el prelado actuaría en estrecha sintonía con Melchor de Aymerich, con el que parece le unían, además de similitudes ideológicas, fuertes lazos de amistad, pues según consta por el testamento de 16 de junio de 1813, era padrino de sus hijos Antonio y $\mathrm{M}^{\mathrm{a}} \mathrm{Rosa}^{32}$. Sus actividades se orientan a contactar con todas las autoridades afectadas para, en unos casos, dejar constancia de su postura fidelista, $\mathrm{y}$, en otros, restar adhesiones al movimiento juntista. Al primer objetivo se dirigen las misivas enviadas a los virreyes de Santa Fe, Antonio Amar y Borbón, de Lima, José Fernando de Abascal y Sousa, y al arzobispo Bartolomé María de las Heras. Al segundo, las cartas enviadas a monseñor Cuero y Caicedo, que se había alineado decididamente al lado de la Junta, al cabildo catedral quiteño y a las comunidades religiosas masculinas y femeninas, instándoles a todos ellos a que se rindan gustosos a la legítima autoridad, y a que confíen en la misericordia y generosidad de $\mathrm{Abascal}^{33}$.

Además de su pluma, empeñó también Quintián, en defensa de la causa realista, su oratoria y sus rentas, pues contribuyó con 51.000 pesos de los bienes eclesiásticos, vistió a su costa la caballería Fernando VII y levantó un columna de sacerdotes para actuar en defensa de la resistencia de Cuenca ${ }^{34}$.

La Junta de Quito, ante la presión militar de los virreyes de Santa Fe y Perú, y el militante realismo de Popayán y Cuenca, no tuvo más salida que la autodisolución y la devolución del poder al Conde Ruiz de Castilla, el 28 de octubre de 1809.

${ }^{31}$ La respuesta se imprimió en Buenos Aires en la Imprenta de los Niños Expósitos, en 1809, y la reproduce J. T. Medina (1892) en La imprenta en Buenos Aires, La Plata, $\mathrm{n}^{\circ} 641$.

32 Aнn/C, Notaría 2, leg. 637, f. 201 r.

${ }^{33}$ Las cartas recibidas y escritas por Quintián se conservan en AGI, Quito 385.

34 Sobre estas actividades: C. DE LA TORRE REYES (1990), La revolución de Quito del 10 de agosto de 1809, Quito: Ecuador F. B. T. Cía. Ltda. y J. PANiagua PÉReZ (1988) «El ejército en la Cuenca del Perú (1808-1812)» en Temas de Historia Militar, III, Zaragoza:. Biblioteca del pensamiento militar, pp. 425-439. 
La persecución y sangrienta represión de los promotores de la Junta y la propia dinámica de los acontecimientos peninsulares -disolución de la Junta Central, establecimiento de la Regencia y convocatoria de las Cortes de Cádiz- conducirían pocos meses más tarde, el 22 de septiembre de 1810, a la constitución de una segunda Junta en Quito, con el respaldo del comisionado regio don Carlos Montúfar, criollo e hijo del Marqués de Selva Alegre, y del obispo Cuero. En principio se planeó como una fórmula transaccional que implicaba el respeto y reconocimiento de la Regencia, pero en pocos días evolucionó hacia la plena ruptura, con la proclamación de la independencia quiteña respecto a Santa Fe y al Consejo de Regencia, aunque ésta no se haría pública hasta el año siguiente.

Tampoco esta segunda Junta lograría el reconociendo de Guayaquil, ni el de Loja, ni, por supuesto, el de Cuenca, que seguiría como núcleo irreductible de la causa relista, sostenido por Aymerich y Quintián.

Montúfar señala al prelado como el principal instigador del envío de tropas de Lima y de la decisión del cabildo cuencano de someterse a la jurisdicción del virreinato peruano y a la autoridad del virrey Abascal. Quintián, lejos de negarlo, se reafirma en lo que considera su principal deber religioso y político: Contrarrestar e impedir que Cuenca sea comprendida en los lastimosos desórdenes de Quito y Santa Fe ${ }^{35}$. Sus redoblados empeños en la movilización de tropas y en la ayuda material al ejército no conocieron tregua. Cuenca se convirtió además, temporalmente, en sede de la Audiencia, al asentarse allí desde enero de 1811 el presidente Joaquín Molina, que sería relevado en el cargo por el más operativo Toribio Montes, a quien correspondería devolver la Audiencia a su sede quiteña, en 1816.

La campaña de Montúfar y la derrota de las tropas dirigidas por Aymerich fuerzan al obispo a abandonar su sede y refugiarse en Guayaquil, donde, según su propio testimonio, permanecería prácticamente dos años. Desde allí seguiría insuflando ayuda monetaria -4.000 pesos- y material -el hierro consignado para la construcción de su casa- a las exhaustas arcas reales ${ }^{36}$. Estos apoyos le supondrían la concesión, por parte del Consejo de Regencia, de la Gran Cruz de Carlos III, el 27 de septiembre de $1811^{37}$.

\footnotetext{
35 AGI, Quito 594, f. 197.

36 J. PANiAgua PÉREZ (1988), «El ejército en la Cuenca...», p. 437.

${ }^{37}$ AhN/M, leg. 7368, doc. 57.
} 
Pese al empuje inicial, el movimiento quiteño terminaría fracasando como consecuencia de la presión del cerco realista y de las divisiones internas. En diciembre de 1812 los realistas dominaban ya el reino de Quito y Quintián podía regresar definitivamente a su sede.

Para entonces, sus años y su intensa actividad habían pasado factura, de manera que en febrero de 1813 se halla tan enfermo que piensa en disponer su testamento. El primer intento de testar se produjo en una fecha indeterminada, pero anterior al día 15 de dicho mes, pues se conserva el comienzo de un testamento, que se corta tras la segunda cláusula con un lacónico no corre, sin que sepamos nada de los motivos de su interrupción ${ }^{38}$. El 18 de febrero de ese año se registra en la misma notaría un testamento en el que se especifica que fue otorgado por Quintián, estando enfermo en cama, y debía ser tal el grado de postración y la debilidad de sus fuerzas, que el escribano se ve obligado a anotar, tras un desvaído garabato: En este estado no pudo firmar, como lo acreditan los caracteres de arriba, por lo trémulo del pulso ${ }^{39}$.

En los meses siguientes el prelado debió de experimentar alguna mejoría, pues el 16 de junio se decidía a redactar un nuevo y definitivo testamento, esta vez cerrado, aunque no de su puño y letra, pues aunque estaba en condiciones de firmar, no pudo escribirlo personalmente, por las incomodidades de las dolencias que padezco ${ }^{40}$. Este último empeño debió agotar sus fuerzas, pues el 24 de ese mismo mes y año se producía su fallecimiento.

Es precisamente en sus testamentos donde podemos comprobar cómo las preocupaciones de Quintián no se agotaron en su militancia en pro de la causa realista, sino que se extendieron también a otras obligaciones más acordes con su condición episcopal. No hay duda de que si los tiempos hubiesen sido otros, nuestro obispo hubiera sido recordado como un clérigo de inquietudes ilustradas, comprometido con la formación del clero y con el seminario, que él no pudo inaugurar, pero al que donó toda su librería, con el encargo especial a los señores del venerable deán y cabildo de esta santa iglesia, para que alternativamente y por turno, hagan de vibliotecarios, procurando su existencia, aseo y conservación, sin permitir de que por modo alguno se extraiga pieza alguna, para que de este modo

${ }^{38}$ El testamento carece de data, pero precede a una escritura notarial fechada el 15 de febrero de 1813. AhN/C, Notaría 2, leg. 637, f.196r.

39 Ahn/C, Notaría 2, leg. 637, f.145r.

${ }^{40}$ Aнn/C, Notaría 2, leg. 637, f.196r. 
se conserve tan interesante mejora ${ }^{41}$. Su labor como diocesano hubiera seguido seguramente derroteros similares a la actividad desarrollada en Concepción como colaborador del obispo Marán, pues el corto espacio que hubo sin convulsiones le fue suficiente para adquirir suelos destinados a una casa de ejercicios, a la que inicialmente dota con 4.000 pesos, que se convierten en 8.000 en su último testamento, y una casa para un hospital de mujeres, al que lega 4.000 pesos, encomendando el patronato de ambas obras pías al deán y cabildo catedralicio ${ }^{42}$. $\mathrm{Si}$ las tareas desempeñadas en Chile con motivo de la peste de 1780 le habían hecho constatar la necesidad de las obras benéfico-asistenciales femeninas, el interés por la casa de la ejercicios entronca también con sus actividades relacionadas con la Escuela de Cristo en la diócesis penquista y con el énfasis que el VI Concilio de Lima puso en que todos los clérigos tuviesen diez días al año de retiro espiritual ${ }^{43}$.

Pero, como bien reconocía el obispo Quintián, su suerte le había conducido a Cuenca en unos tiempos tan calamitosos, que su efectividad organizativa y su generosidad hubieron de volcarse, no en el desarrollo del culto y la vida pastoral, sino en la defensa de unos valores que él consideraba intrínsecamente unidos a la fe en Dios, la fidelidad a la Corona y la salvaguarda del orden establecido.

\section{LOS TESTAMENTOS. ANÁLISIS FORMAL Y CONTENIDO}

Desde la óptica de sus testamentos, Andrés Quintián se nos revela como un hombre previsor, ordenado y entre desconfiado y voluble.

Tan pronto como conoció su promoción al obispado de Cuenca, consciente de las dificultades del largo viaje que le esperaba hasta su sede, se aprestó a dejar ordenados todos sus asuntos, otorgando poder para testar, en abril de 1806, a Salvador de Andrade, canónigo de la Concepción, y a don Francisco Javier Manzano, coronel de milicias ${ }^{44}$. Javier Manzano de la Sota era un hacendado, que estaba casado Rosario Alemparte Vial, criolla, hija de un comerciante gallego

${ }^{41}$ La cita corresponde a la $5^{\text {a }}$ cláusula del testamento otorgado el 18 de febrero de 1813 y se repite, con pocas variantes de redacción, en el de 16 de junio, como se puede contrastar en el apéndice. AHN/C, notaría 2, leg. 637, ff. 138v y 196v

42 AHN/C, notaría 2, leg. 637, ff. 138 y 196v.

${ }^{43}$ VI Concilio de Lima, Libro III, tit. 1, cap. 20. R. VARGAS UgARTE (1952), Concilios limenses (1551-1772), Lima: Tip. Peruana, pp. 74-75.

${ }^{44}$ De ese poder, conservado en el Archivo Nacional, en la sección Notarial de Concepción, vol. 6, f.6, nos da noticia H. RodríGUEZ VILlEGAS (1992), «Andrés Quintián», p. 622. 
asentado en la Concepción a finales del siglo XVIII ${ }^{45}$. En cuanto a Salvador Andrade y Bohórquez, era un presbítero oriundo de Concepción, que coincidió con Quintián en el seminario, del que fue vicerrector en 1780, y también en su condición de capellán militar, y de canónigo catedralicio (1795); de hecho Andrade sería quien le sucedería en el oficio de vicario general, cuando, en la sede vacante abierta por la muerte del obispo Roa y Alarcón, don Andrés fue promovido al episcopado. Aquí se agotan las coincidencias, pues Salvador Andrade, adoptando una posición radicalmente opuesta al obispo cuencano, fue uno de los primeros sacerdotes en impulsar la causa patriota y un estrecho colaborador de Juan Martínez de Rozas ${ }^{46}$.

Al margen de este poder, nos consta por el testimonio de los testamentos redactados en Cuenca, que el obispo había otorgado uno cerrado, poco antes de salir de Concepción, que conservaba, en el monasterio de trinitarias descalzas de la ciudad, la madre Magdalena de la Cruz y que era el que reconocía como válido hasta la redacción de los de 1813. Nada conocemos de él, salvo que lo da por nulo en todo su contenido a ecpeción (sic) de una cláusula relativa a veneficio de dicha madre Magdalena, ordenando, para que tuviese pleno cumplimiento que, recogiendo dicho testamento y abriéndolo sin otro requisito y solemnidad que este expreso permiso, remita a mis albaceas copia, firmada de su mano, de la cláusula expuesta, dirigiéndola por triplicado para evitar algún estravio...; y para que tenga su debido efecto esta mi disposición, es mi voluntad que la referida copia de dicha cláusula se inserte y agregue al presente testamento con la solemnidad de derecho, y se tenga con una con las de este testamento, para su debida execución ${ }^{47}$.

En Cuenca también van a ser dos los documentos de última voluntad otorgados. El primero es un testamento nuncupativo, formalizado el 18 de febrero ante D. José Villavicencio, escribano mayor de gobierno y guerra, y secretario de cámara y real acuerdo de la Audiencia y del cabildo cuencano, y cuatro testigos: el racionero Manuel Carrión, el teniente coronel don José de Neyra y Vélez, el relator de la Audiencia don José Joaquín Aguilar y el cura de Pucará, don Mariano Beltrán ${ }^{48}$. El

45 Alguno noticia indirecta: A. PACHECO Y SiLVA «Los comerciantes de la Concepción, 18001820» en http://www2.udec.cl/historia/rhistoria/art11.doc

${ }^{46}$ Nos proporciona algún dato sobre la trayectoria del arcediano chileno F. CAMPOS HARRIET (1992), «Diego Antonio Navarro Martín de Villodres», en C. Oviedo Cavada, Episcopologio..., T. IV, pp. 512-513.
${ }^{47}$ Aнn/C, Notaría 2, leg. 637, f. 143.
${ }^{48}$ AHN /C, Notaría 2, leg. 637, f. 144. 
segundo se otorgó cerrado con siete pegas de lacre encarnado y apuntado con una ebra de ceda amarilla ${ }^{49}$. Se formalizó el 16 de junio, siendo el redactor material, ante las limitaciones que tenía el obispo para escribir, el racionero Juan Antonio de la Magdalena Jaramillo Tavera, por ser persona -dice- de mi entera satisfacción y confianza y de el necesario y correspondiente sigilo. Su sobrescrito va autorizado por el escribano José Villavicencio y los testigos Diego Fernández de Córdoba, Pablo Hilario Chica y Astudillo, Félix del Castillo, Manuel Landívar, Domingo Sobrecilla, José Ignacio Valencia, Bruno de Lorenzo de Neyra y el alcalde Diego de Córdoba, y en él, como era habitual, el expreso encargo, prevención y advertencia que de ningún modo se habra entretanto no conste en bastante forma el fallecimiento de su Excelencia Ilustrísima ${ }^{50}$.

No es fácil aventurar qué razones movieron a don Andrés Quintián a otorgar este segundo testamento y a hacerlo secreto. Tal vez su carácter le impedía, por lo reservado o lo influenciable, mostrar su libre voluntad en escrituras y actos públicos. Después de una vida orientada a obrar conforme a los valores establecidos, el obispo actuaba en público como se esperaba de él, como entendía que era su deber, pero no como le dictaban sus sentimientos y conciencia. No decimos esto porque haya grandes diferencias de contenido entre uno y otro testamento, más bien por lo que tiene su proceder de repetitivo en Concepción y Cuenca.

Puesto que el último de los testamentos anula y revoca los anteriores, centraremos en él nuestro análisis, aunque iremos apuntando las similitudes y diferencias existentes con el precedente.

Formal y jurídicamente el testamento de Quintián responde al modelo regulado por las Partidas, que se mantendría, sin variaciones sustanciales hasta el final del Antiguo Régimen ${ }^{51}$.

El encabezamiento sigue la fórmula simple de invocación divina que es la habitual en los testamentos a partir del siglo XVIII: En el nombre de Dios todo poderoso. Amén. A continuación se añade el nombre del testador y algunas de sus circunstancias personales: lugar de nacimiento, nombre de sus progenitores, títulos $\mathrm{y}$ cargos que ostenta, para pasar a renglón seguido a señalar su estado físico $\mathrm{y}$, sobre todo, mental, puesto que de la cordura de otorgante dependía la validez legal

\footnotetext{
${ }^{49}$ AHN /C, Notaría 2, leg. 637, f. 195.

${ }^{50}$ AHN /C, Notaría 2, leg. 637, f. 195r.

${ }^{51}$ Partidas III, tit. XVIII, leyes 102-104.
} 
del documento: hallándome enfermo, pero en pie y en mi sano juicio, memoria y entendimiento natural ${ }^{52}$. La salud mental había de estar certificada además por el escribano ante el que se validaba el testamento, de manera que en el del 18 de febrero, al final de la cláusula 37, se lee: Yo don José Villavisencio y Andrade... certifico conosco al excelentísimo e ilustrísimo señor obispo de esta diócesis doctor don Andrés Quintián Ponte y Andrade, y que aunque // se halla enfermo en cama, se halla, al parecer en su entero juicio, memoria y entendimiento natural, según sus palabras bien ordenadas y consertadas, con que ha manifestado todas las disposiciones de su última voluntad constantes en este testamento; en el de junio el testimonio se incluye en el sobrescrito, afirmándose que aunque enfermo de salud se halla en pie, en su sano juicio, memoria y entendimiento ${ }^{53}$.

A continuación se desarrolla la profesión de fe, requisito indispensable para dejar constancia de que el otorgante era miembro consciente y fiel de la Iglesia y por ello digno de ser enterrado en sagrado y capaz de testar, derecho que desde las Partidas estaba vedado a judíos y herejes ${ }^{54}$. Ésta se limita a manifestar la creencia en el misterio trinitario y en todos los demás misterios y sacramentos que tiene, cree y confiesa nuestra Santa Madre, la Iglesia, Católica, Apostólica Romana, y a declarar que en esa fe se ha vivido y se desea morir ${ }^{55}$.

Las cláusulas confesionales se completaban siempre con la mención a los intercesores elegidos y una sucinta alusión a la concepción de la muerte. La mención a ésta se limita en el testamento de Quintián a la estereotipada expresión sobre su inexorabilidad y la incertidumbre de su hora. En cuanto a la fórmula de intercesión, que se inscribe en la tradición cristiana y en la ortodoxia fijada en Trento, responde al modelo que se generaliza a partir de la segunda mitad del siglo XVII, pues incluye la invocación a la Virgen como madre de Dios, al Ángel de la Guarda, a los santos del nombre y devoción del testador y a todos los demás santos y santas de la corte del Cielo. De todos ellos se espera su intercesión para que rueguen a nuestro señor Jesucristo, para que por los infinitos méritos de su santísima vida, pasión y muerte, perdone todas mis culpas y lleve mi alma a gozar

\footnotetext{
52 Partidas VI, tit. I, ley 1 y AHN/C, Notaria 2, leg. 637, f. 196.

53 AHN /C, Notaria 2, leg. 637, ff. 144 y 195r.

${ }^{54}$ Partidas VI, tit. XVI, ley 4.

${ }^{55}$ AнN /C, Notaria 2, leg. 637, f. 196r.
} 
de su beatifica presencia ${ }^{56}$, expresión que denota la concepción del testamento como "pasaporte a la salvación"

Por el específico carácter del último testamento de Quintián, tras las disposiciones confesionales se dedican unas líneas a explicar la razón, ya aludida, por la que hubo de ser escrito por el racionero Jaramillo, para dar paso a continuación a las cláusulas dispositivas.

La primera de éstas se dedica invariablemente en todos los documentos de última voluntad a la prevención del enterramiento y se inicia con una referencia, de raíz platónica, a la concepción dual del hombre, mediante expresiones del tipo a: Encomiendo a Dios mi alma, que de la nada la crió, y mando el cuerpo a la tierra, del que fue formado ${ }^{58}$. El obispo cuencano no especifica nada sobre la elección de la mortaja ni sobre el desarrollo de su entierro. No es extraño, pues como hemos tenido oportunidad de constatar, la generalizada costumbre de que los clérigos se enterrasen con las vestiduras litúrgicas y la tendencia cada vez más extendida de delegar muchas de estas decisiones en los albaceas, parece hacer innecesaria cualquier disposición al respecto ${ }^{59}$. Por lo demás, desde que en 1614 se impusiera el ritual romano, el desarrollo de honras y funerales había quedado ya perfectamente configurado ${ }^{60}$. Sí se ocupa en cambio de la elección de la sepultura, que de acuerdo a su dignidad ha de situarse en la catedral, en el medio del presbiterio; en el testamento de febrero, advierte, respecto a esta cuestión, que en el caso de trasladarse el coro y servicio -se refiere al catedralicio- a la que fue de los regulares expatriados del nombre de Jesús, quiero que en tal caso se traslade también mi cuerpo a la bóveda de ella ${ }^{61}$; sin embargo, en el de junio, suprime tal aviso e incluye la orden de que sus albaceas no consientan que se le aplique a su

${ }^{56}$ AнN /C, Notaria 2, leg. 637, f. 196r.

${ }^{57}$ Ese carácter ha sido puesto de relieve por J. LE GOFF (1969), la civilización del Occidente Medieval, Barcelona: Paidos, p. 263 y Ph. ARIES (1984), El hombre ante la muerte, Madrid: Taurus, p. 163.

${ }^{58}$ AHn /C Notaría 2, leg. 637, f. 138r.

${ }^{59} \mathrm{La}$ ausencia de disposiciones sobre mortaja, entierro y exequias se generaliza a partir de la segunda mitad del XVII, como puede constatarse en Ma I. VIFORCOS MARINAS y J. PANIAGUA PÉREZ (2001), «"El clero secular de Cuenca (Ecuador): Actitudes ante la muerte (1651-1705)», Estudios Humanisticos , 22 , pp. 157-181.

60 P. M. Gy (1955), «Les funerailles d'après le Rituel de 1614» La Maison-Dieu, 44 y M. RighetTi (1955), Historia de la liturgia, T. I, Madrid, BAC, pp. 968-1008.

${ }^{61}$ Aнn/C, Notaria 2, leg. 637, f. 138r. 
cuerpo ninguna ceremonia de embalsamamiento, haciendo renuncia expresa a tal privilegio; tal deseo, por lo que tiene de desprecio al cuerpo, de nuevo le vincula al ascetismo rigorista de la espiritualidad de las escuelas de Cristo ${ }^{62}$.

La falta de disposiciones sobre las preceptivas misas de funeral y exequias, bastante común en los testamentos del XVIII, responde seguramente al hecho de que estos aspectos habían quedado ya regulados por el VI Concilio límense, en cuyo título De episcopis se estipulaba la obligación del cabildo de no llevar derecho alguno por el entierro de su prelado y la de todos los sacerdotes seculares de la diócesis de aplicar dos misas en sufragio por su alma ${ }^{63}$. Eso sí, consciente Quintián de la reconocida importancia de los sufragios y, en particular, de la eucaristía, para la salvación del alma, instituye una manda ordenando el reparto de 200 pesos de limosna entre presbíteros pobres y de buena vida, para que le digan otras tantas misas que se han de celebrar en los días anteriores y posteriores a mi entierro $^{64}$. Además grava la cesión de sus casas, que lega a sus sucesores en el episcopado, con 300 pesos, de los cuales 50 correspondían a los réditos de un censo que ya tenía sobre sí la casa, y el resto se destina a una memoria de 63 misas anuales, de las que 33 habían de decirse los jueves en honor del Santísimo Sacramento, devoción potenciada por la Escuela de Cristo, y las demás, los sábados no festivos, en honor a la Inmaculada, advocación que había estado muy presente en la vida del obispo, pues como hemos visto buena parte de su trayectoria vital se había desarrollado en la localidad chilena de Concepción y, en Cuenca, la catedral de su sede estaba destinada a este mismo misterio; tales misas deberían ser solemnes, pues se ordena que al oficiante se le entregasen 20 reales y a los prebendados que actuasen de acólitos, a 12 reales cada uno ${ }^{65}$.

Como en cualquier expresión de última voluntad, también en el testamento de Quintián hay lugar para las mandas pías o legados de caridad, que también participan de la condición de sufragios redentores. La relación comienza , como era habitual, con las conocidas como mandas forzosas. El texto explicita dos de los legados obligatorios: el sostenimiento del culto del Santo Sepulcro, custodiado por la orden de San Francisco, y la redención de cautivos cristianos, que constituía el carisma específico de los mercedarios. A ellas se había añadido, desde la pragmática de 11 de febrero de 1623, la destinada a dotar a huérfanas pobres para

\footnotetext{
${ }^{62}$ AHN /C, Notaria 2, leg. 637, f. 196r. Vid apéndice, cláusula 1.

${ }^{63}$ VI Concilio limense, libro III, T. II, cap. 2. R. VARgas Ugarte (1952), Los concilios..., p. 78.

${ }^{64}$ AHN /C, Notaría 2, leg. 637, f. 203r.

${ }^{65}$ AHN /C, Notaría 2, f. 197. Vid apéndice, cláusula 10.
} 
que pudiesen tomar estado ${ }^{66}$. En cuanto a la última aludida-la prevenida por $S u$ Majestad en su última real pragmática del caso- se refiere a la instituída por el real decreto de las Cortes de Cádiz de 3 de mayo de 1811, que se hace público por real cédula de 20 de mayo de ese año, y consistía, para los territorios americanos, en tres pesos, destinados al socorro y alivio de los beneméritos de la Patria, que, ocupados sus bienes y careciendo de otros auxilios, padecen en poder del tirano y sufren cruel cautividad por la religión, por nuestro legítimo rey, y por nuestra gloriosa independencia, debiendo ser socorridos, inclusas su familias, si su conducta fuese fiel y arreglada, teniendo en consideración sus servicios a la patria, y los méritos y circunstancias de cada uno ${ }^{67}$. El obispo se muestra magnánimo con todas ellas, pues los 15 pesos legados superan con creces los 36 maravedís de mínima que estuvieron en vigor hasta el 16 de septiembre de 1813 , en que la cuantía se incrementa para los territorios de ultramar hasta los 60 reales ${ }^{68}$.

En cuanto a las mandas o legados voluntarios responden a tres intereses fundamentales: su iglesia, la familia y su entorno social.

Para su obispado instituye los legados destinados a la casa de ejercicios, para la que ya en vida había comprado el solar necesario, y a la que como hemos visto deja 8.000 pesos; al hospital de mujeres, al que lega 4.000 pesos para los gastos de la remodelación de la casa que ya había donado y de su mantenimiento, dejando como patronos de una y otro al cabildo catedralicio. Al seminario, como ya se ha dicho, le deja su librería, de la que lamentablemente no conocemos ni el número de volúmenes, ni los títulos y autores, datos que hubieran sido de gran interés para acabar de perfilar el carácter del obispo cuencano. Eso sí intuimos que debían alcanzar una cantidad considerable, a juzgar por las normas estipuladas para su conservación, que implican hasta la prevención del oficio de bibliotecario. Para sus sucesores en la mitra deja sus casas, a fin de que sirvan de palacio episcopal, pero con los mencionados 300 pesos de carga, y advirtiendo que, de no admitirse el legado, el edificio debería arrendarse, total o parcialmente, para que produjese la expresada cantidad destinada al pago de los réditos del censo que pendía sobre él y los 250 pesos que destinaba a misas por su alma, y las de sus familiares y por sus obligaciones. Por último el cabildo catedralicio es el destinatario de la lámina de plata con la cruz de la orden de Carlos III grabada, que fue obsequió del cabildo de

\footnotetext{
${ }^{66}$ Novísima Recopilación, libro I, tit. XVII, ley 9.

${ }^{67}$ AHN /M, Cédulas reales, $\mathrm{n}^{\mathrm{o}} 1892$, art. $2^{\mathrm{o}}$.

68 J. De Ayala (1991), Diccionario de gobierno... T. IX, p. 7.
} 
Guayaquil, y que el obispo quiere que se fije en la sala capitular para perpetua memoria de la donación y del donador ${ }^{69}$.

Las donaciones familiares tienen como beneficiarias principales a su hermana y sus sobrinas. A su hermana María Quintián, vecina de La Coruña, la lega ciertas cantidades de dinero que ha ido remitiendo a la Península y han ido entrando en poder de su apoderado José Rojo de los Ríos, vecino de dicha ciudad, para cubrir las necesidades de su manutención, más la parte que le corresponde por su legítima de la hacienda y bienes dejados por sus progenitores. En caso de muerte de su hermana, las beneficiarias han de ser cuatro sobrinas, hijas de su hermano Juan, que estaban avecindadas en Cádiz. El rasgo más curioso de estas donaciones es la apostilla que incluye tras referirse a las remesas monetarias enviadas desde América, que dice: para poder hazer estos socorros he procurado deducirlos economizando los gastos de mi persona; tal advertencia denota una clara preocupación por la opinión ajena que nos ayuda a comprender el porqué de la inclinación a los testamentos secretos. A las hijas de Gregorio Somoza, que también llama sobrinas, las lega una casa y hacienda de su propiedad, de las que nada dice sobre su valor y ubicación; tal vez el hecho de que el encargado de gestionar esta donación sea el arcediano de Concepción, Salvador Andrade, sea indicativo de que pudiesen ser propiedades sitas en el entono de esa localidad, donde tal vez vivirían las beneficiarias ${ }^{70}$.

En cuanto a los legados destinados a su entorno social, todos parecen emanar del afecto o del agradecimiento por los servicios prestados. Algunos tienen una carácter claramente benéfico-asistencial, así ordena se le remitan 1.000 pesos a don Antonio Martín de Salcedo, con el que, a juzgar por su apellido le uniría su común origen gallego, además de buena amistad y correspondencia, para contribuir a los adelantamientos de su hijo. A dos familiares suyos, probablemente no de sangre sino de trato, llamados José Fernández y Manuel Barrera, les lega dos mil pesos, al primero para que puedan servirle de sustento hasta que haga carrera o tome estado $^{71}$, al segundo, en agradecimiento a la buena asistencia con que le había servido. Para José María Plaza de los Reyes, clérigo, deja prevenida una ayuda de 1.000 pesos, para el caso de que, transcurrido un año y medio de la muerte del

\footnotetext{
${ }^{69}$ Vid apéndice, cláusulas 3, 4, 5, 10 y 28.

${ }^{70}$ Vid apéndice, cláusulas 14,15 y 16.

${ }^{71}$ En el testamento de febrero dispone que esa cantidad se entregue como depósito a don José María Landa, clérigo realista en quien recaería el gobierno de la diócesis a la muerte de Quintián y hasta la llegada del obispo José Ignacio Cortázar. AHN/C, Notaría 2, leg. 637, f.140v.
} 
obispo sin haber conseguido beneficio alguno, quisiese regresar a España. Incluye también un legado a favor de la madre Magdalena de la Cruz, monja en el convento trinitario de Concepción, aunque nada se concreta sobre él, por hallarse especificado en la cláusula del testamento secreto que la religiosa custodiaba; y otro a favor de la madre Manuela de la Santísima Trinidad, carmelita en el convento de Cuenca, a la que cede la mitad de una quadra nombrada Guatana, que había dejado a ambos, a su muerte, el maestro Casimiro Astudillo, para que la religiosa pudiese gozarla entera y libremente ${ }^{72}$.

Como manda pía o de caridad hemos de considerar los 500 pesos a repartir entre pobres vergonzantes según el criterio del racionero Jaramillo, el mismo que le sirve de amanuense para el testamento. Entendemos que también tiene ese carácter la rebaja en cien pesos sobre el valor de compra de tres esclavos de su propiedad llamados Ramón, Manuel y Antonio María, de los que dice ser el primero criollo, y los otros bozales; tal rebaja sólo tiene sentido si lo que se pretende es dar facilidades para que puedan comprar su propia libertad, porque, de albergar otra intención, lo lógico hubiese sido recomendar la venta al mejor precio posible para incrementar los bienes del testador. Tal vez también se debiese a la generosidad del obispo los 500 pesos dejados a su criada María Candelaria, pues aunque en esta ocasión se especifica que son en remuneración por su servicio, no se constata que se le debiera cantidad alguna de su salario. Por último, también hemos de contar entre los legados motivados por la gratitud, los 100 pesos dejados a favor de Manuel Moreno, que además de haber servido a Quintián los dos años de estancia en Guayaquil, le había acompañado a su regreso a Cuenca, y los mismo las cantidades dejadas a Francisco Ibáñez -otros cien pesos- y a Juan Manuel Bernal -50 pesos $^{73}$.

Otro fundamento distinto tiene la manda incluida en el testamento de junio y ausente en el otorgado en febrero, por el que se beneficia a los hijos del gobernador Melchor de Aymerich y su esposa Josefa Montero y Espinosa, un niño llamado Antonio y una niña de nombre $\mathrm{M}^{\mathrm{a}}$ Rosa, con 1.000 peso para cada uno, por su condición de ahijados del prelado y por el cariño que éste les profesa; lo que viene a confirmar que además de la identidad ideológica con la causa realista, existieron también lazos personales de amistad entre el obispo y el gobernador ${ }^{74}$.

\footnotetext{
72 Apéndice documental, cláusulas 6, 17, 18, 19, 23 y 24

73 Apéndice documental cláusulas 20, 21, 30 y 36.

${ }^{74}$ Apéndice documental, cláusula 37.
} 
Capítulo obligado en todo testamento es la declaración de deudas y la relación de los bienes del otorgante. Como suele ocurrir en este tipo de documentación, la vaguedad y la imprecisión son las notas dominantes, lo que imposibilita cualquier aproximación a la fortuna de Andrés Quintián, que intuimos saneada aunque no demasiado importante, pues su única fuente de ingresos parece provenir de las rentas de sus oficios. En el testamento queda claro que tuvo casa en propiedad, no sólo las que en Cuenca actuaron de palacio episcopal, sino también posiblemente en Concepción; que al morir poseía tres esclavos, artículo tan suntuario ${ }^{75}$ como la plata labrada mexicana que dice tener en Guayaquil, o la de su servicio corriente, cuyas piezas no concreta, en el primer caso, por tener hecha una relación que guarda, entre otros documentos, en sus papeleras o escritorios, $\mathrm{y}$, en el segundo, por considerar que son de sobra conocidas ${ }^{76}$ De ese conjunto de piezas, sólo han llegado hasta nuestros días, dos platones, un lavapiés y seguramente la peana de plata de un crucifijo que perteneció al obispo y que se componía de cruz de madera y cristo de marfil ${ }^{77}$. Posee, como no podía ser menos, un pontifical y diversos ornamentos, además de ropa blanca y de color, pero nada se nos dice sobre la calidad o tipo de piezas, de modo que sólo podemos hacernos una idea vaga de su cantidad, teniendo en cuenta que la relación de las mismas ocupaba cuatro listas que el obispo había dejado entre sus documentos, y que a ellas se añadía el contenido de nueve baúles y tres escritorios, más algunas mercancías y útiles comprados en Guayaquil, que componían quince cargas que, en el momento de la redacción del testamento, aún no habían llegado a Cuenca, calculándose su valor en unos 300 pesos que se adeudaban a Domingo Ordeñana, comerciante guayaquileño al que se habían adquirido. Finalmente debe contabilizarse igualmente en su haber algún capital personal más, de cuya cuantía dice tener documentos, cuya aprobación la han retardado las circunstancias de el tiempo, originadas de las conmociones de la ciudad de Quito ${ }^{78}$.

Tampoco el testamento es demasiado explícito por lo que hace a sus deudas, aunque de algunos pagos pendientes sí deja constancia. Así, ordena se remitan a la Península algunas cantidades adeudadas por diversos servicios: tres mil pesos por la gestión de las bulas episcopales a su agente Manuel José de Amandaro; dos mil,

75 J. Paniagua Pérez (1986), «La esclavitud en Cuenca del Perú (1770-1810)», Estudios Humanísticos, 8, pp. 121-143.

${ }^{76}$ Apéndice documental, cláusulas 26 y 27.

77 Sobre estas piezas: J. PANIAGUA PÉREZ (1997), El trabajo de la plata en el sur del Ecuador durante el siglo XIX, León: Universidad de León, pp. 85, 133 y 134.

${ }^{78}$ Apéndice documental, cláusulas 8,32 y 38 . 
sin especificar el concepto, a doña María Rosa Landívar; a Pedro Javier de la Vera, el honorario que le correspondiese como agente suyo en la Corte; y a Miguel Moreno, residente en Cádiz, el equivalente a los gastos que declare haber hecho por su causa ${ }^{79}$

En el ámbito americano debe 300 pesos a Ordeñana, por las mercancías adquiridas en Guayaquil; a Francisco Javier de Venegas, cura de Chiloé, lo que constare según la cuenta de Salvador de Andrade; desea además que se salden y den por buenas las cuentas presentadas por Bruno Neyra, de los gastos habidos desde el regreso del obispo a Cuenca ${ }^{80}$.

Por si hubiera algún olvido, completa la relación de deudas con la habitual y estereotipada cláusula: declaro que por la misericordia de Dios no debo a otras personas más, pero si después de mi fallecimiento saliere algunas o alguna demandando en poca o mucha cantidad, mando que mis albaceas, prebia la necesaria justificación, paguen de mis bienes. Y lo expongo para que conste ${ }^{81}$.

El testamento es ocasión obligada de poner orden, más allá de en las deudas materiales, en otra serie de obligaciones y encargos no cumplidos por el otorgante. Algunas de las que afectan a Quintián se refieren a obligaciones contraídas en su condición de albacea testamentario. Declara, en efecto, haberlo sido del doctor Jacinto Murillo, canónigo de la Concepción, quien a su vez lo había sido del penitenciario Juan de San Cristóbal, y que al tiempo de trasladarse a su obispado había dejado el encargo de culminar ambas testamentarias al arcediano Salvador Andrade, a lo que le insta estrechamente, advirtiendo que se le han de entregar 1.000 pesos, que correspondían a unas cuentas pendientes favorables a la testamentaría del citado Murillo. Otras parecen responder al mero hecho de haber sido considerado persona de confianza. A esta condición y, sin duda a la del común origen gallego, responde el compromiso de remitir a España el monto de un legado que el maestro de ceremonias de la Concepción, Juan Pérez, había dejado para sus tres hermanas; lo azaroso de los tiempos había impedido cumplir el encargo hasta entonces, por lo que ordena se solicite a Salvador Andrade que envíe traslado de dicha cláusula al apoderado del obispo en La Coruña, José Rojo de los Ríos, para que, de las cantidades que obraban en su poder, satisficiese dicho legado. También en la confianza se había basado el encargo recibido de don Gaspar Morales,

\footnotetext{
79 Apéndice documental, cláusulas 6, 7, 9 y 11.

${ }^{80}$ Apéndice documental, cláusulas 8,12 y 22

${ }^{81}$ La cita corresponde al testamento de febrero (AHN/C, Notaría 2, leg,. 637, f.142v), pero se repite literalmente, como puede comprobarse, en el apéndice cláusula 29.
} 
corregidor de Guaranda y oidor honorario de la Real Audiencia, para remitir 200 pesos a España, que ordena se ejecute en el primer correo ${ }^{82}$. No todos los asuntos pendientes tienen que ver con temas crematísticos, pues también señala como preocupación el que no se haya podido adjudicar la capellanía que el maestro Astudillo había dejado fundada sobre la cuadra que había legado por mitades al obispo y a la carmelita madre Manuela, por no haber aparecido, hasta el momento, ningún interesado, disponiendo que su sucesor se ocupase de proveerla, dando los edictos convenientes, en quien por derecho le correspondiese ${ }^{83}$.

Sus gestiones como defensor de la causa realista no asoman prácticamente en el testamento. Sólo dos referencias se pueden vincular a ellas, una sólo aparece en el formalizado en febrero, en cuya cláusula 32 se lee: Yten declaro que de lo primero que se recaudase de mis rentas, y deducido y satisfecho lo que queda en este testamento dispuesto, se entreguen al señor Marqués de Casa Calderón ${ }^{84}$, aquellas cantidades que debo satisfacer por razón de donativo voluntario, conforme a la cédula de treinta y uno de diciembre de mil ochocientos onze, para pagar los sueldos de los ministros del Consejo y demás subalternos de él, por estar designadas las rentas del Estado para la manutención del exército. Y lo expongo para que conste ${ }^{85}$. Tal vez ya se había satisfecho el donativo en junio, porque no hay referencia ninguna en el segundo testamento, donde sí se repite en cambio una cláusula en la que se da cuenta que al morir el dominico Francisco Pasos, habían quedado por sus expolios 2.000 pesos, que correspondían a la cantidad prestada a las cajas reales para el socorro de las tropas realistas, cantidad que el obispo desea revierta al convento de Santo Domingo de Guayaquil en atención a su estado de deterioro y a su necesidad de ornamentos para el culto ${ }^{86}$.

${ }^{82}$ Apéndice documental cláusula 13, 29, 34 y 35.

${ }^{83}$ Apéndice documental, cláusula 24.

${ }^{84}$ Se trata de don Gaspar de Cevallos y Calderón, jurista y noble limeño, que fue rector de la Universidad de San Marcos de la capital virreinal entre 1809 y 1813.

${ }^{85}$ Ahn/C, Notaría 2, leg. 637, f.143r.

${ }^{86}$ En el testamento de febrero se dice: declaro que por fallecimiento del reverendo padre fray Francisco Pasas, del orden de predicadores, quedaron por su expolios dos mil pesos, los mismos que se presentaron para el socorro de las tropas del Rey, y deben reintegrar las caxas reales de la ciudad de Guayaquil a la disposición de los prelados de la capital, los quales los distribuirán conforme a derecho y en consideración a las estremas necesidades en que se halla el convento de predicadores de Guayaquil, pues carece de ornamentos y hasta de corporales y purificadores, de sercas que aseguren la clausura de él. En estos mismo términos se incluye la disposición en la cláusula 25 del formalizado en junio, como puede constatarse en el apéndice. 
Como encargados de cumplir fielmente su última voluntad, en ambos testamentos, Quintián señala como albaceas a dos prebendados catedralicios, Fausto Sodupe, maestrescuela, y Juan Antonio Jaramillo Tavera, racionero, de forma mancomunada, dándoles poder, según la fórmula habitualmente empleada en los testamentos del Antiguo Régimen, para que constando de mi fallecimiento se apoderen de mis bienes y los vendan en almoneda o fuera de ella, y con su producto se cumplan todas mis disposiciones, pues para ello, su anexo, conexo, incidente y dependiente, les confiero poder bastante y qual por derecho es necesario, prorrogándoles, como les prorrogo, a más del año fatal, el más tiempo que necesiten $^{87}$.

Tras señalar como su heredera universal a la iglesia catedral de Cuenca, el último testamento de Quintián se cierra con las cláusulas revocatorias de todos los redactados con anterioridad, la data y una temblorosa firma autógrafa, puesto que al ser cerrado no hay más testigos que los que figuran en el sobrescrito, para dar fe de la entrega del documento al escribano Villavicencio.

Como hemos visto no es el documento de última voluntad de Quintián demasiado rico en detalles sobre su persona y posición económica, tampoco lo es en cuanto a sus relaciones sociales, aunque es evidente que su círculo estaba compuesto esencialmente por clérigos, sobre todo del cabildo catedralicio, y servidores de la Corona, tanto en el plano militar como en el administrativo, ocupando un papel relevante, a lo que parece, los vínculos de paisanaje. No es habitual que los testamentos revelen datos innovadores de sus otorgantes, porque las cláusulas en las que se alude a disposiciones ya comunicadas a personas de confianza o, como hemos señalado, a relaciones, escritos y documentos diversos dejados a disposición de los albaceas en escritorios, cajas o baúles, nos hurtan buena parte de la información. Pero es indudable que eso no resta valor a su estudio, porque siempre permite, cuando se estudia particularmente, matizar la semblanza del testador, y cuando se hace en conjunto, agrupando muestras cuantitativamente amplias, verificar los comportamientos, las prácticas religiosas y la mentalidad dominante en la época o el grupo de testadores objeto de estudio. Con este análisis del testamento de don Andrés Quintián creemos haber contribuido a arrojar luz sobre su perfil más olvidado, el de preocupado diocesano y generoso valedor de su familia.

${ }^{87}$ El texto citado pertenece a la cláusula 35 del testamento otorgado en febrero (AHN/C, Notaría 2, leg. 637 , ff. $143 \mathrm{v}-144 \mathrm{r}$ ), pero es idéntica a la empleada en junio, como puede constatarse en el apéndice documental, cláusula 39 
Prepararse a bienmorir: las últimas voluntades del obispo cuencano Andrés...

\section{APÉNDICE DOCUMENTAL}

1813, junio, 16. Cuenca.

Testamento cerrado otorgado por don Andrés Quintián Ponte y Andrade, obispo de Cuenca (Ecuador).

Archivo Histórico Nacional de Cuenca (Ecuador), Notaría 2, 637, ff. 195- 201.

En la muy noble, fidelísima y valerosa ciudad de Santa Ana en la Nueva Cuenca en el Perú a diez y seis de junio de mil ochocientos trece, ante mí don José Villavicencio y Andrade, escribano mayor de gobierno y gracia, secretario del excelentísimo cavildo de esta ciudad y del excelentísimo supremo general de la Audiencia de este distrito, en su Cámara y Acuerdo, y de los testigos que abaxo se expresarán, presente en su palacio episcopal el excelentísimo e illlustrísimo señor doctor don Andrés Quintián Ponte y Andrade, cavallero gran Cruz de la distinguida orden de Carlos tercero del Consejo de Su Majestad, digno obispo de esta diócesis, a quien certifico y doy fe conozco, y que aunque enfermo de la salud se halla en pie, en su sano juicio, memoria y entendimiento natural; y que entregándome su excelencia ilustrísima el presente pliego serrado con siete pegas de lacre encarnado y apuntado con una ebra de ceda amarilla, expresó y aseguró que dentro de él estaba el testamento y última voluntad que habia hecho, con la protestación de la fe, señalamiento de sepultura y nombrado heredero y albacea, con las demás cláusulas que han sido necesarias para el descargo de su conciencia; con encargo y prevención y advertencia que de ningún modo se habra entretanto no conste en bastante forma el fallecimiento de su Ilustrísima, por ser esta su deliverada voluntad. Y en su testimonio así lo dice, otorga y firma, siendo testigos el señor docto don Pablo Ylario Chica, don Félix del Castillo, presbitero; don Manuel Landivar, don Domingo Sobrevilla, don José Ignacio Valencia; el señor alcalde doctor don Diego Córdova y el presbítero don Bruno Lorenso de Neyra, precentes vecinos de esta dicha ciudad, de que doy fee.

Andrés obispo de Cuenca (rúbrica). Diego Fernández de Córdoba (rúbrica) testigo Pablo Ylario Chica y Astudillo (rúbrica); testigo Félix del Castillo (rúbrica); testigo Domingo Sobrevilla (rúbrica); testigo Bruno Lorenso de Neyra (rúbrica); testigo José Ignacio Valencia (rúbrica); testigo Manuel Landivar (rúbrica); (signo) José Villavicencio y Andrade (rúbrica).

En el nombre de Dios todo poderoso. Amén. Sepan quantos esta carta de testamento vieren, como yo, el doctor don Andrés Quintián Ponte y Andrade, natural de la ciudad y puerto de la Coruña; hijo legítimo de don Bernardo Josef de Quintián y de doña María Isabel Ponte y Andrade; obispo de esta iglesia catedral por la gracia de Dios y de la Santa Sede Apostólica, caballero gran cruz de la real y distinguida orden de Carlos Tercero; hallándome enfermo, pero en pie y en mi sano juicio, memoria y entendimiento natural; creyendo, como firmemente creo, en el altísimo inefable e incomprehensible misterio de la Santísima Trinidad, Padre, Hijo 
y Espíritu Santo, tres personas que, aunque realmente distintas, tienen un mismo ser y naturaleza divina, y en todos los demás misterios y sacramentos que tiene, cree y confiesa nuestra Santa Madre, la Iglesia, Católica, Apostólica Romana, en cuya fee $y$ creencia he vivido, vivo y protesto vivir y morir, como verdadero y fiel cristiano; tomando por mi intercesora a la Santísima Virgen María, madre de Dios y señora nuestra, y por mis abogados al santo ángel de mi guarda, a los santos de mi nombre y deboción, y a todos los demás santos y santas de la Corte de el cielo, para que rueguen a nuestro señor Jesucristo, para que por los infinitos méritos de su santísima vida, pasión y muerte, perdone todas mis culpas y lleve mi alma a gozar de su beatifica presencia, temeroso de la muerte, que es natural y forsosa a toda viviente criatura, como incierta su hora, y para que quando ésta llegue no me coja desprevenido, hago y ordenó este mi testamento escrito, que comúnmente se llama cerrado, el qual no haciendolo de mi puño, letra, por las incomodidades de las dolencias que padesco, lo he hecho escribir de puño y letra del racionero de esta santa iglesia, don Juan Antonio de la Magdalena Xaramillo Tavera de mi espresa orden por ser persona de mi entera satisfacción y confianza y de el necesario $y$ correspondiente sigilo, en la forma y manera siguiente:

$1^{a}$ Primeramente encomiendo a Dios mi alma, que de la nada la crió, y redimió, y mando el cuerpo a la tierra, del que fue formado; el qual, siendo hecho cadáver, quiero y es mi voluntad se le dé eclesiástica sepultura en la Santa Iglesia Catedral de esta ciudad, y en el medio de su presviterio; que para ello se omita precisamente la ceremonia de embasamarle, porque renuncio este privilegio, quiero y es mi voluntad que de ningún modo se execute, lo prohivo y estrechamente ordeno y mando a mis albaceas y a los que corresponda el funeral, no lo permitan, celebrando sólo el entierro en las demás ceremonias conforme al carácter y dignidad. Y lo expongo para que conste.

$2^{a}$ Yten mando que de lo mejor y más bien parado de mis vienes se den a las casas santas de Jerusalén, redempción de cautivos cristianos y demás mandas pías, forzosas y acostumbradas, a quinse pesos a cada una, y por sola una vez; $y$ también otros quinse pesos a la prevenida por Su Majestad en su última real pragmática del caso. Y lo expongo para que conste.

$3^{a}$ Yten declaro que es mi voluntad se den de lo más bien parado de mis vienes, ocho mil pesos para la fábrica y demás necesarios de la casa de exercicios, cuyo suelo y citio lo tengo comprado antes de aora, según consta de los documentos de adquisición que existen y a que me remito. Expóngolo así para que conste.

$4^{a}$ Yten declaro que asimismo es mi voluntad se den de mis vienes quatro mil pesos para los gastos de fábrica y más necesarios del hospital de mugeres, que se han de hazer en la casa que a este efecto tengo comprada antes de aora. El patronato de estas dos obras pías de la casa y capilla de exercicios y de el hospital de mugeres, lo encomiendo al venerable señor deán y cavildo de esta santa iglesia 
Prepararse a bienmorir: las últimas voluntades del obispo cuencano Andrés...

catedral, bien satisfecho de el zelo y piedad con que procurarán su más pronto cumplimiento y conservación. Y lo expongo para que conste.

$5^{a}$ Yten declaro que es mi voluntad se dé al seminario de esta ciudad toda la librería de mi uso y propiedad para el servicio de él, con encargo especial a los señores del venerable deán y cavildo de esta sana iglesia, para que alternativamente y por turno, hagan de bibliotecarios, procurando su existencia, aseo y conservación, sin permitir que por modo alguno salga ningún libro suelto o en juego, fuera del seminario o biblioteca donde se coloque, para que de este modo permanezca integra tan útil y aseada mejora. Y lo expongo para que conste.

$6^{a}$ Yten declaro que a don Manuel José de Amandaro, residente en la corte, o a sus herederos que su persona y derechos representare, se le den de mis vienes, tres mil pesos, para los gastos que se hizieron en la consecución de bulas, según debe pareser de la quenta que me remitió y existe en mi secretaría. Asimismo es mi voluntad se le remitan junto con los antecedentes, un mil pesos a don Antonio Martín Salcedo, a quien por buena amistad y correspondencia quiero se le den para los adelantamientos de su hijo; encargo a mis albaceas den noticia de esta cláusula a sus interesados a la posible mayor brevedad. Y lo expongo para que conste.

$7^{a}$ Yten declaro que a doña María Rosa Landivar y San Andrés tengo que darle dos mil doscientos quarenta y quatro pesos, según debe constar de un papel otorgado por don Bruno Neyra y tiene dicha doña María Rosa en su poder; mando se le satisfagan. Y lo expongo para que conste.

$8^{a}$ Yten declaro que a don Domingo Ordeñana de el comercio de Guayaquil, tengo que darle trescientos pesos; mando se satisfagan de mis vienes. Y lo declaro para que conste.

$9^{a}$ Yten declaro que es mi voluntad que a don Pedro Xavier de la Vera, agente de negocios en la corte de España, se le abone el honorario correspondiente a mi dignidad, por el tiempo que ha servido de agente de mis negocios en dicha corte. $Y$ lo expongo para que conste.

$10^{a}$ Yten quiero y es mi voluntad que la casa de mi propiedad que hoy sirve de palacio episcopal, se dé a mis sucesores, siempre y quando que cada uno de ellos la quiera, con el cargo de satisfacer trescientos pesos por cada año. De ellos los cinquenta pesos para la satisfacción de los réditos por el principal que sobre sí tienen las dichas casas, y los doscientos sinquenta pesos como pensión de este legado; los quales se han de invertir en sesenta y tres misas que se han de celebrar por los señores de el venerable deán y cavildo de esta santa iglesia, que tengan altar, distribuyéndose por iguales partes entre cada uno de dichos señores, en la forma siguiente: veinte reales para el que diga la misa y doce reales para los dos prevendados que la acolitaren, cuya aplicación se hará por mi alma y de aquellos a quienes yo tuviese alguna obligación, diziéndose de ellas las treinta y 
tres en honra y gloria del Santísimo Sacramento del Altar, en los días juebes, y las treinta restantes a honra y gloria de la Santísima Virgen María, en el misterio de su Inmaculada Concepción, en los días sábados libres, poniéndose para ello en principio de cada año una tablilla en la sacristía, que manifieste a los señores a quienes toca celebrarlas. Y en el caso de vacante, como igualmente en el de no quererla ocupar los ilustrísimo señores obispos, se arrendará a la persona que la quisiere en el todo o en parte, a efecto de que todo su resulto se invierta en las misas que quedan expresadas, siendo de obligación del que la ocupe, repararla a satisfacción del venerable señor deán y cabildo. Lo que expongo para que conste.

$11^{a}$ Yten declaro que es mi voluntad que al señor doctor don Miguel Moreno, residente en Cádiz, se le abonen todos los gastos que por mía haya hecho en la Península, sin otro documento que la cuenta que presentare $Y$ lo expongo para que conste.

$12^{a}$ Yten declaro que tengo una quenta con el doctor don Francisco Xavier Benegas, cura de Chiloé, mando que ésta se transe a la mayor brevedad, con arreglo a lo que consta de la correspondiente con el señor arcediano de la Concepción de Chile doctor don Salvador de Andrade. Y lo expongo para que conste.

$13^{a}$ Yten declaro que fui albasea del doctor don Jacinto Murillo, canónigo de merced de la Concepción de Chile, quien igualmente lo havía sido del doctor don Juan de San Cristóval, canónigo penitenciario de dicha iglesia, y haviendo, para venirme, dejado todos estos asunptos al cargo del señor doctor don Salbador Andrade, arcediano de la misma iglesia, le encargo estrechísimamente con la responsavilidad de consiencia, que concluya y finalice dichas testamentarías, con todos sus incidentes, a la mayor brevedad; para lo qual mis albaceas le darán parte, judicial y extrajudicialmente, urgiéndole su total cumplimiento, y poniendo en su noticia que de mis vienes, mando a mis dichos albaceas se le entreguen un mil pesos, pertenecientes a la testamentaría de el tal doctor Murillo, los quales procedieron de una quenta pendiente que estuvo a mi cargo y ha resultado a favor de dicha testamentaría, para que estos se agreguen a la masa de vienes y sobre ellos recaigan las disposiciones testamentarias de el enunciado dotor Murillo. Y lo expongo para que conste.

$14^{a}$ Yten declaro que ratifico, doy por firme y valedera en todas sus partes, la donación que en virtud de órdenes privadas, hiso el señor doctor don Salbador Andrade, arcediano de Concepción de Chile, a mi nombre, a mis sobrinas, hijas de don Gregorio Somosa, de la casa y hazienda que fueron de mi propiedad, según ha de constar del documento de propiedad respectivo, que quiero se tenga por uno con esta cláusula, que en todo evento les servirá de instrumento de propiedad qual por derecho se requiere, para su validación y firmeza, por ser ésta mi deliverada voluntad. Y lo expongo para que conste. 
$15^{a}$ Yten declaro que en poder de don Josef Rojo de los Ríos, vecino de la ciudady puerto de la Coruña, tengo algunas cantidades de pesos, los que deberán ser en mayor número con los que le deben llegar últimamente remitidos por mí. Éstos tienen el destino de sobstener la diaria manutención y alimentos de la señora doña María Quintián, mi hermana legítima, perpetuamente valetudinaria. Por tanto declaro que es mi voluntad que se consuman en dichas sus asistencias, y si llegase el caso de que fallesiese y quedasen algunos restos de ellas, mando y ordeno, bien satisfecho de la condugta de el citado don José Rojo de los Ríos, que los tales sobrantes de dichos dineros los remita y mande entregar a mis quatro sobrinas, vecinas de la ciudad y puerto de Cádiz, hijas de mi difunto hermano don Juan Quintian a esta iglesia. Para poder hazer estos socorros he procurado deducirlos economisando los gastos de mi persona. Y lo expongo para que conste.

$16^{a}$ Yten declaro que en la ciudad y puerto de la Coruña tengo que haver mi legítima paterna y materna en las posesiones y heredades de mis mayores, cuya porción y herencia, quiero que la posea la señora doña María Quintián, mi hermana valetudinaria, para su habitación y subsistencia. Y en el caso de su fallecimiento, quiero y es mi voluntad, que lo hayan y posean con título de legítima propiedad y con la bendición de Dios y la mía, mis quatro sobrinas, vecinas de Cádiz, hijas de el señor don Juan Quintián, mi hermano difunto, en quienes cedo, dono y traspaso el dominio de propiedad, que a esa parte de fundos tengo, para que dividida en quatro iguales partes cada una de dichas mis sobrinas, la parte que le toque y quepa, los goze y posea, venda, done o traspase en quien quiera, como dueño legítimo a su entera voluntad y disposición. Para lo qual ordeno y mando que de esta cláusula y de la antecedente, que trata de sobrantes, se saquen copias auténticas y por triplicado se remitan así a don Josef Rojo de los Ríos, como a dichas mis quatro sobrinas, para que les sirva de gobierno y de título de propiedad; a todo los dicho el señor doctor don Miguel Moreno será por cuya mano se remitan para que este señor entregue los tales testimonios a las enunciadas mis sobrinas. Y lo declaro para que conste.

$17^{a}$ Yten declaro que es mi voluntad que de lo más bien parado de mis bienes se separen dos mil pesos y se reserven en poder de mis albaceas, para que, en llegando la edad correspondiente a poder manejarse por sí, se los entreguen a don Josef Fernández, mi familiar, por los buenos servicios y cristianos procedimientos que le he observado desde que lo tengo a mi lado; los quales quiero que sirvan para su substentación en qualesquiera carrera que emprenda o estado que tome. Y lo expongo para que conste.

$18^{a}$ Yten declaro que es mi voluntad que de lo más bien parado de mis bienes se le den a don Manuel Barrera, mi familiar, dos mil pesos para que los destine y aprobeche con la bendición de Dios y la mía, y se haya por satisfecho de los buenos servicios con que me ha asistido en los tiempos que ha estado bajo de mi mando y familia. Y lo expongo para que conste. 
$19^{a}$ Yten declaro que quiero y es mi voluntad de que en caso de que Don Josef María Plaza de los Reyes no obtenga beneficio curado o simple que le sostenga en esta diócesis o en otra cualquiera parte dentro de un año y medio del día de mi fallecimiento, y quisiere regresar a su patria, se le den de lo más bien parado de mis bienes, un mil pesos para los costos de su transporte. Pero si dentro de tal tiempo obtuviese curato o prevenda, o aunque no los obtenga, no quisiese bolver a su patria, no se le dará cosa alguna. Y lo expongo para que conste.

$20^{a}$ Yten quiero que a mi criada María Candelaria se le den de mis bienes quinientos pesos, en pago y remuneración de su servicio personal, para que con ellos se sobstenga. Y lo expongo para que conste.

$21^{a}$ Yten declaro que es mi voluntad que a mis esclavos, nombrados Ramón, Manuel y Antonio María, el primero criollo y los dos vosales, se les rebaje a cien pesos a cada uno de ellos del valor que tuvieron al tiempo que se compraron, con calidad expresa de que tan solamente puedan ser vendidos en la cantidad que remaniere, hecha la mencionada rebaja a cada uno, y de ningún modo en mayor por ser ésta mi deliberada voluntad. Y lo expongo para que conste.

$22^{a}$ Yten declaro que es mi voluntad que a don Bruno Neyra se le pase la última quenta que éste presentare de los gastos que han corrido por su mano desde mi regreso de la ciudad de Guayaquil, quedando asuelto de los anteriores gastos y cuentas producidas, sin que en el particular se innove cosa alguna. Y lo expongo para que conste.

$23^{a}$ Yten declaro que por cláusula de testamento del finado maestro don Casimiro Astudillo, tengo derecho a la mitad de una quadra nombrada Guatana y a la otra mitad lo tiene la madre Manuela de la Santísima Trinidad, religiosa carmelita de esta ciudad. Quiero que este derecho que a mi me corresponde recaiga igualmente en la expresada religiosa para que absolutamente sea dueño de toda ella; y al efecto de que pueda aceptar, desde luego, le concedo la lizensia necesaria. Y lo expongo para que conste.

$24^{a}$ Yten declaro que hasta la fecha no se ha probeido la adjudicación de la capellanía que expresa el maestro don Casimiro Astudillo tener la quadra expresada en la cláusula anterior, a causa de no haver comparecido interesado alguno. Mando que el ordinario convoque por edictos y adjudique a quien por derecho le corresponda, para evitar los perjuicios que puedan seguirse con la mayor demora. Y lo expongo para que conste.

$25^{a}$ Yten declaro que por fallecimiento del reverendo padre fray Francisco Pasos, del orden de predicadores, quedaron por su expolios dos mil pesos, los mismos que se presentaron para el socorro de las tropas del Rey, y deben reintegrar las caxas reales de Guayaquil a la disposición de los prelados de la capital, los quales los distribuirán conforme a derecho y en consideración a las estremas necesidades en que se halla el convento de predicadores de Guayaquil, pues 
Prepararse a bienmorir: las últimas voluntades del obispo cuencano Andrés...

carece de ornamentos y hasta de corporales y purificadores y de cercas que aseguren la clausura de él. Y lo expongo para que conste.

$26^{a}$ Yten declaro que en poder de don Martín de Ycasa, vecino de la ciudad de Guayaquil, tengo un servicio de plata labrada en México, que consta de muchas piezas, cuyo por menor aparecerá de los documentos que existen en mis papeleras. En el poder del mismo don Martín tengo plata en cruz, cuya cantidad ha de constar igualmente de sus respectibos documentos que también existen en mis arcas. Mando que mi albacea lo recauden todo y agreguen al cúmulo de mis bienes. Y lo expongo para que conste.

$27^{a}$ Yten declaro que la plata labrada de mi servicio corriente está en poder del doctor don Bruno Neyra y don Manuel Barrera, y por bien conocida no lo individualizo. Mando se agregue a mis bienes. Y lo expongo para que conste.

$28^{a}$ Yten declaro que es mi voluntad que una lámina de plata que existe en mi poder y la misma que el excelentísimo cavildo de la ciudad de Guayaquil, en señal de su gratitud, me obsequió, y en la que se halla gravada la gran cruz de la distinguida orden de Carlos Tercero, con que se dignó la soberanía condecorarme. Mando que se dé a mi cavildo, eclesiástico y venerable señor deán para que la fixen en la sala capitular, para memoria del excelentísimo cuerpo que la ofreció y que para ello y su constancia se dé una copia certificada de esta cláusula, para que el notario de cavildo la archive en él, como es de derecho, y porque toda es mi última y deliverada voluntad. Y lo expongo para que conste.

$29^{a}$ Yten declaro que por la misericordia de Dios no debo a otras personas cantidad alguna, pero si después de mi fallecimiento, saliesen alguno o algunos demandando en poca o mucha cantidad, mando que mis albaceas, previa la necesaria justificación, según derecho, paguen de mis vienes lo que resulte. Y lo expongo para que conste.

$30^{a}$ Yten mando que de lo más bien parado de mis vienes se saquen quinientos pesos para que se den a las personas más pobres y vergonzantes a discreción del señor prevendado don Juan Antonio de la Magdalena Xaramillo Tavera y según se lo he comunicado. Y lo declaro para que conste.

$31^{a}$ Yten mando que de lo más bien parado de mis vienes, se saquen doscientos pesos para que se den de limosna para otras tantas misas que se han de celebrar en los dias anteriores y posteriores a mi entierro para los sacerdotes pobres y más exemplares.

$32^{a}$ Yten declaro que a más de las casas, esclavos, plata labrada y dinero que tengo expresado en las cláusulas anteriores, dejo por mis bienes el pontifical, ornamentos, ropa blanca y de color, que todo consta de quatro listas en que se expresan, con más todo lo que se encontrare en nueve baúles y tres papeleras; igualmente lo que resultare de quince cargas, poco más o menos, de comestibles y 
útiles para el servicio de palacio, que se hallan en el camino de Guayaquil a esta ciudad. Y lo expongo para que conste.

$33^{a}$ Yten declaro que en años pasados, antes de salir de el obispado de Concepción de Chile, otorgué testamento serrado, que quedó en el monasterio de Trinitarias Descalsas de dicha ciudad en poder de la madre Magdalena de la Cruz. El qual testamento quiero y es mi voluntad que se abra por el señor arcediano doctor don Salvador Andrade en junta de dicha madre Magdalena de la Cruz, y que conferenciando entre los dos todas sus cláusulas, si alguna o algunas necesiten cumplirse, se cumplan en los términos en que lo resuelva dicha madre, por la entera satisfacción que tengo en su virtud y prudencia y además en los conocimientos que tiene en dichas materias, con el que puede resolver qualquiera duda que ocurra. Y como si yo la resolviese se pasará enteramente por ello, y fecha que sea esta diligencia, se quemará dicho testamento, quedando como queda para lo sucesivo irrito, de ningún valor ni efecto. Ordeno asi mismo y mando que para toda esta actuación tengan presente dicho señor arcediano y la madre Magdalena la lista que acompaño a este mi testamento, firmada por mí, a efecto de que en las copias auténticas de esta cláusula que por triplicado se les remitirá por mis albaceas, a dicho señor arcediano y madre Magdalena para su inteligencia y operación, se incluyan las copias de la indicada lista. Y lo expongo para que conste

(34) Yten declaro que el licenciado don Juan Pérez, maestro de ceremonias de Concepción de Chile, natural del reyno de Galicia, dejó un legado a favor de sus tres hermanas y de los descendientes legítimos de ellas, como consta de la cláusula de su testamento, otorgado en dicha Concepción en el oficio de cavildo por ante su escribano don Carlos Martínez, cuyo legado no ha tenido efecto a cauza de las guerras de estos años. Es mi voluntad y encargo a mis albaceas que con copia jurídica de esta cláusula escriban al señor arcediano doctor don Salvador Andrade, para que este señor, sacando copia auténtica de la cláusula del testamento del citado lizenciado don Juan Pérez, la remita hasta por triplicado a mi apoderado don Josef Rojo de los Rios a la ciudad y puerto de la Coruña, para que éste, del dinero mío que tiene en su poder para las asistencias de mi hermana la señora doña María Quintián, saque la cantidad correspondiente al legado, y la distribuya entre las dichas tres hermanas del testador licenciado Pérez en sus legítimos desendientes, con arreglo a las cláusulas citadas; de la qual, si el triplicado no bastare, se embiarán las copias que fueren necesarias, así a mi apoderado el caballero Rojo, como a la interesadas si es asequible. Y lo expongo para que conste.

(35) Yten declaro que el señor don Gaspar Morales, corregidor de Guaranda y oidor honorario de la Real Audiencia de Quito, me remitió doscientos pesos, con encargo de que los dirigiese a la Península a disposición del señor doctor don Miguel Moreno, su apoderado. Mando que mis albaceas, de mis vienes, los 